Article

\title{
Design and Synthesis of Novel Hybrid 8-Hydroxy Quinoline-Indole Derivatives as Inhibitors of $A \beta$ Self-Aggregation and Metal Chelation-Induced A $\beta$ Aggregation
}

\author{
Suresh K. Bowroju ${ }^{1}$, Nirjal Mainali ${ }^{2}{ }^{\circ}$, Srinivas Ayyadevara ${ }^{3}$, Narsimha R. Penthala ${ }^{1}{ }^{\oplus}$, \\ Sesha Krishnamachari ${ }^{3}$, Samuel Kakraba ${ }^{2}{ }^{\circledR}$, Robert J. Shmookler Reis ${ }^{2,3,4}$ and \\ Peter A. Crooks ${ }^{1, *}$ \\ 1 Department of Pharmaceutical Sciences, College of Pharmacy, University of Arkansas for Medical Sciences, \\ Little Rock, AR 72205, USA; skbowroju@uams.edu (S.K.B.); NRPenthala@uams.edu (N.R.P.) \\ 2 Bioinformatics Program, University of Arkansas at Little Rock and University of Arkansas for Medical \\ Sciences, Little Rock, AR 72205, USA; nmainali@ualr.edu (N.M.); SKAKRABA@uams.edu (S.K.) \\ 3 Central Arkansas Veterans Healthcare Service, University of Arkansas for Medical Sciences, \\ Little Rock, AR 72205, USA; sesha@uams.edu (S.K.); AyyadevaraSrinivas@uams.edu (S.A.) \\ 4 Department of Geriatrics, College of Medicine, University of Arkansas for Medical Sciences, \\ Little Rock, AR 72205, USA; ReisRobertJ@uams.edu \\ * Correspondence: PACrooks@uams.edu
}

Academic Editor: Wei Li

Received: 16 July 2020; Accepted: 7 August 2020; Published: 8 August 2020

\begin{abstract}
A series of novel hybrid 8-hydroxyquinoline-indole derivatives (7a-7e, 12a-12b and 18a-18h) were synthesized and screened for inhibitory activity against self-induced and metal-ion induced $A \beta_{1-42}$ aggregation as potential treatments for Alzheimer's disease (AD). In vitro studies identified the most inhibitory compounds against self-induced $A \beta_{1-42}$ aggregation as $\mathbf{1 8 c}$, $\mathbf{1 8 d}$ and $\mathbf{1 8 f}$ $\left(\mathrm{EC}_{50}=1.72,1.48\right.$ and $1.08 \mu \mathrm{M}$, respectively) compared to the known anti-amyloid drug, clioquinol (1, $\left.\mathrm{EC}_{50}=9.95 \mu \mathrm{M}\right)$. The fluorescence of thioflavin T-stained amyloid formed by $\mathrm{A} \beta_{1-42}$ aggregation in the presence of $\mathrm{Cu}^{2+}$ or $\mathrm{Zn}^{2+}$ ions was also dramatically decreased by treatment with 18c, 18d and 18f. The most potent hybrid compound $\mathbf{1 8 f}$ afforded $82.3 \%$ and $88.3 \%$ inhibition, respectively, against $\mathrm{Cu}^{2+}$ - induced and $\mathrm{Zn}^{2+}$ - induced $\mathrm{A} \beta_{1-42}$ aggregation. Compounds $18 \mathrm{c}, 18 \mathrm{~d}$ and $\mathbf{1 8 f}$ were shown to be effective in reducing protein aggregation in HEK-tau and SY5Y-APP ${ }_{S w}$ cells. Molecular docking studies with the most active compounds performed against $\mathrm{A} \beta_{1-42}$ peptide indicated that the potent inhibitory activity of $\mathbf{1 8 d}$ and $\mathbf{1 8 f}$ were predicted to be due to hydrogen bonding interactions, $\pi-\pi$ stacking interactions and $\pi$-cation interactions with $A \beta_{1-42}$, which may inhibit both self-aggregation as well as metal ion binding to $A \beta_{1-42}$ to favor the inhibition of $A \beta_{1-42}$ aggregation.
\end{abstract}

Keywords: Alzheimer's disease; clioquinol analogues; hybrid 8-hydroxyquinoline-indole analogs; A $\beta$-aggregation; metal chelating agents

\section{Introduction}

Alzheimer's disease (AD) is the most debilitating age-associated neurodegenerative disorder leading to dementia, affecting millions of elderly people, and the number of patients is expected to reach 130 million worldwide by 2050 [1,2]. AD remains incurable due to the low efficacy and the very limited number of available drugs to treat this neurodegenerative disease. Salient features of $\mathrm{AD}$ are the accumulation of amyloid- $\beta(\mathrm{A} \beta)$ plaques and tangles containing hyperphosphorylated tau protein. These proteins misfold and aggregate in the brains of affected individuals as amyloid 
senile plaques outside the neurons and neurofibrillary tangles (NFTs) within neurons, which are diagnostic for AD but accompanied by dyshomeostasis of biometals [3,4]. Current treatments for AD include acetylcholinesterase (AChE) inhibitors (i.e., tacrine, donepezil, rivastigmine, and galantamine), and $N$-methyl-D-aspartate (NMDA) antagonists, the only drugs approved for AD which provide a symptomatic relief strategy for mild forms of AD [5]. Unfortunately, there is currently no means to cure or even slow the progression of $\mathrm{AD}$ [6], spurring increased efforts to develop more effective drugs to prevent or treat AD. Due to the complexity of AD and the multitude of factors potentially involved in its progression, a strategy that uses multi-target directed ligands (MTDLs) has drawn much attention as a mainstream therapeutic approach for treatment of this disease [7-11].

The deposition of $\mathrm{A} \beta$ plays a crucial role in the pathogenesis of $\mathrm{AD}$ [12]. Many studies have shown that $A \beta$ forms consist of several different types of aggregates, such as oligomers and fibrils $[13,14]$. Among these aggregates, soluble $\mathrm{A} \beta$ oligomers produce the most potent neurotoxicity and are generally regarded as the main neurotoxins in $\mathrm{AD}$. Soluble $\mathrm{A} \beta$ oligomers not only lead to cognitive impairment in rodents but also induce neuronal death in primary neurons and neuronal cell cultures [15]. Soluble A $\beta$ oligomers rapidly interact with neuronal cell membranes, produce free radicals, and increase the levels of intracellular reactive oxygen species (ROS) [16]. Moreover, A $\beta$ oligomers induce neuronal apoptosis by regulating signaling pathways, such as glycogen synthase kinase $3 \beta$ (GSK3 $\beta$ ) and mitogen-activated protein kinase (MEK)/extracellular signal-regulated kinase (ERK) signaling [16]. In addition, metal ions such as $\mathrm{Cu}^{2+}, \mathrm{Zn}^{2+}, \mathrm{Fe}^{2+}$, and $\mathrm{Fe}^{3+}$ are required for neuronal activity within synapses. Due to the necessity of these metal ions, cells have a sophisticated system to maintain metal-ion homeostasis. Breakdown of these mechanisms alters the ionic balance and can result in aggregation of A $\beta$ peptide into plaques, and production of reactive oxygen species induced by $A \beta$. Elevated levels of these metal ions can readily bind to $A \beta$ via histidine residues $H 6, H 13$, and $H 14$, facilitating $A \beta$ aggregation [17-21] and generating reactive oxygen species (ROS) via Fenton-like reactions, which lead to oxidative stress and eventual neuronal death in AD patients [22]. Thus, clearance of A $\beta$ amyloid in the brain by targeting metal ions effectively detoxifies the $\mathrm{A} \beta$ plaques, and has become a promising approach for inhibition of $A \beta$ aggregation $[17,20,22]$. These metal ions are also implicated in the formation of hyperphosphorylated tau and tau tangles [23].

Clioquinol (CQ, 1, Figure 1), and PBT2 (2, Figure 1) exhibit moderate affinity for $\mathrm{Cu}^{2+}$ and $\mathrm{Zn}^{2+}$ and can inhibit metal-induced $\mathrm{A} \beta$ aggregation and ROS generation in vitro [24-27]. Recently, 8-hydroxyquinoline-based multi-target-directed ligands (MTDLs), such as M30, HLA20, WBQ5187, and tacrine-8-hydroxyquinoline hybrids, have been developed for treatment of AD. These compounds significantly inhibit $A \beta$ aggregation in vitro and improve cognition in vivo in mouse models [28-31]. Interestingly, the melatonin- $N$-benzylamine hybrids (3, Figure 1), which have an indole framework, can promote the effective development of neural stem cells into the neuronal phenotype [32,33]. The current study focuses on a series of molecules that incorporate the indole moiety and the 8-hydroxyquinoline moiety into a novel 8-hydroxyquinoline-indole hybrid structure (Figure 2; left panel). The fifth and seventh position of the 8-hydroxyquinoline moiety has also been varied by replacing the hydrogen atoms with chloro or bromo groups, followed by conjugation of these 8-hydroxyquinoline moieties to indole or 5 fluoro-, 5-chloro- or 5-methoxyindole scaffolds to improve binding affinity and metal ion selectivity. In addition, recent studies have reported that incorporating a piperazine moiety into these MTDL molecules affords significant inhibition of A $\beta$ aggregation [34], which prompted us to design a second set of hybrid molecules by inserting a piperazine bridging moiety between the 8-hydroxyquinoline and indole scaffolds (Figure 2; right panel) to afford a series of novel 8-hydroxyquinoline indole ester and amide analogs as multitarget-directed drugs in AD. 


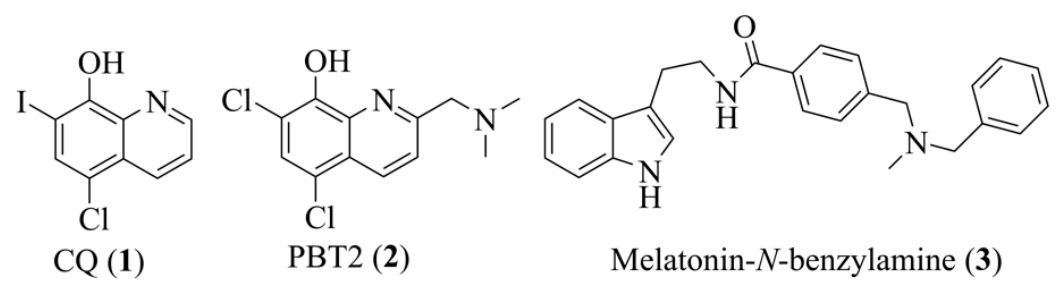

Figure 1. Chemical structures of multitarget-directed drugs clioquinol (1), PBT2 (2), and melatonin- $N$-benzylamine (3).

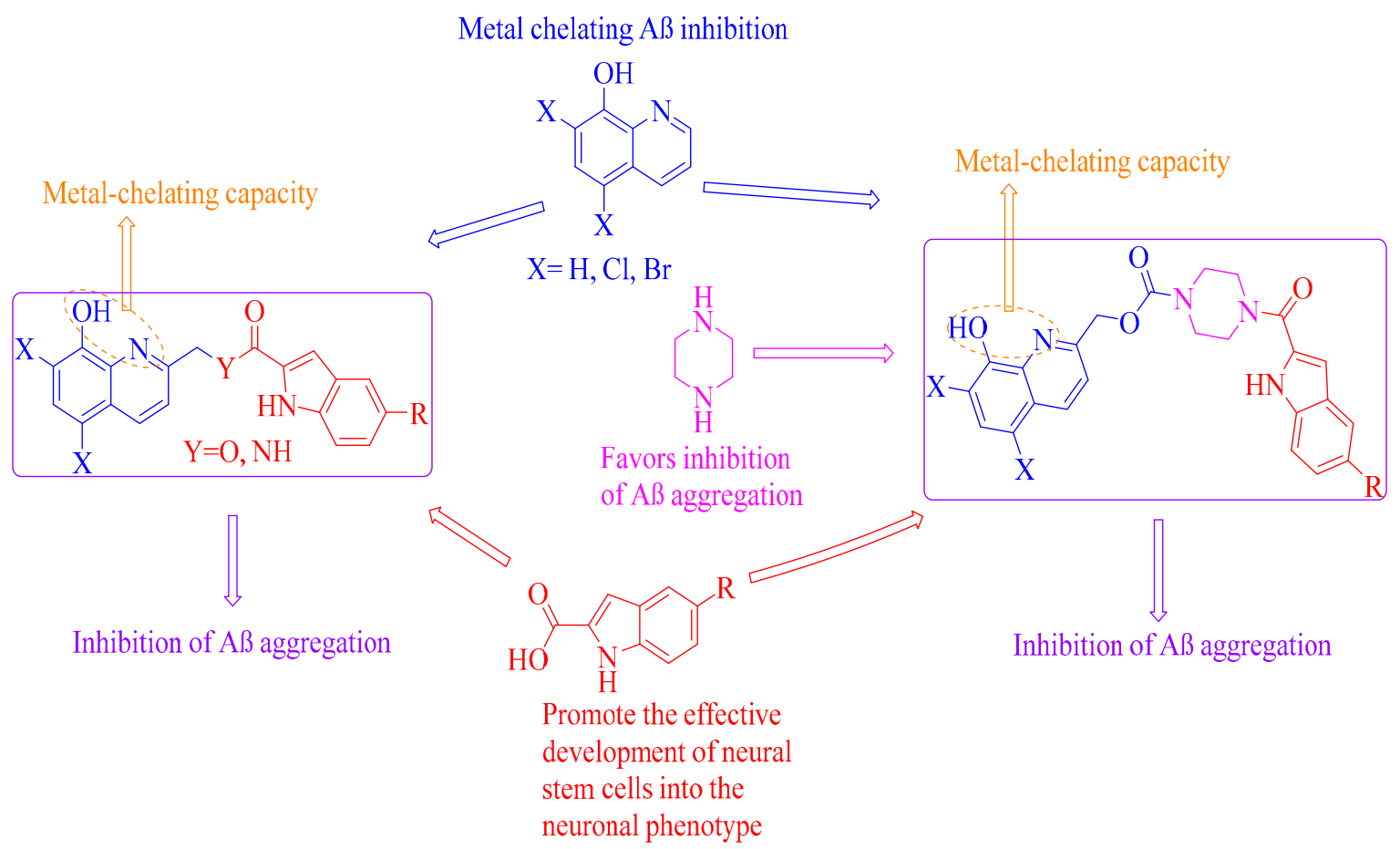

Figure 2. Design strategy for hybrid 8-hydroxyquinoline-indole ester and amide analogs with and without a piperazine-bridging moiety as multitarget-directed drugs for Alzheimer's disease (AD) therapy.

Taking into account neuronal loss, deficits in adult neurogenesis, and the formation of plaques and tangles associated with $\mathrm{AD}$, the present work is focused on the identification of pharmacophores containing the 8-hydroxyquinoline moiety conjugated to an indole scaffold, in order to generate a series of hybrid 8-hydroxyquinoline indole esters and amides without (7a-7e and 12a-12b) and with a piperazine bridging moiety (18a-18h). Fifteen novel hybrid 8-hydroxyquinoline-indole analogs of this type were prepared and investigated for their inhibition of $A \beta_{1-42}$ self-aggregation and metal ion-induced aggregation. Compounds which showed inhibitory activity against self-induced $A \beta_{1-42}$ aggregation were also evaluated against HEK-tau and $\mathrm{SY} 5 \mathrm{Y}-\mathrm{APP}_{\mathrm{SW}}$ cells to determine their effects on cellular protein aggregation.

For the synthesis of hybrid 8-hydroxyquinoline indoles (7a-7e), we initially prepared tert-butyl (2-(hydroxymethyl)quinolin-8-yl) carbonates $4 \mathbf{a}$ and $\mathbf{4 b}$ utilizing literature procedures [35], and carried out EDC coupling of each compound with a variety of indole-2-carboxylic acids (5a-5c) to afford Boc-protected ester intermediates 6a-6e. Boc-deprotection of intermediates 6a-6e was carried out with trifluoroacetic acid in dichloromethane at room temperature to afford 7a-7e (Scheme 2).

For the synthesis of hybrid $\mathrm{N}$-((5,7-dichloro-8-hydroxyquinolin-2-yl)methyl)-1H-indole-2carboxamides (12a-12b), the key intermediate 2-(aminomethyl)-5,7-dichloroquinolin-8-yl tert-butyl carbonate (10) was prepared by reacting intermediate $4 \mathrm{~b}$ [35] with iodine in the presence of $\mathrm{PPh}_{3}$ and imidazole in dichloromethane, for $1 \mathrm{~h}$ at room temperature, to afford iodo-intermediate 8 . The product 
was then reacted with sodium azide, at reflux temperature in acetone for $6 \mathrm{~h}$, to afford the azido intermediate 9 . Compound 9 was then reduced to the amino compound 10 by treatment with $\mathrm{PPh}_{3}$ in water at $60{ }^{\circ} \mathrm{C}$ for $12 \mathrm{~h}$ (Scheme 1).

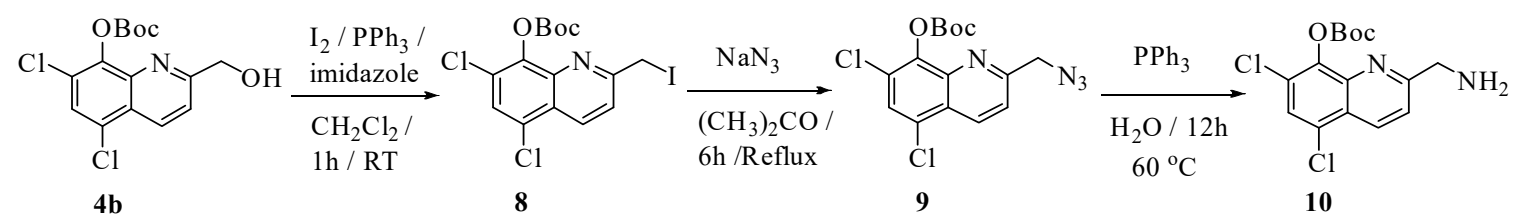

Scheme 1. Synthesis of 2-(aminomethyl)-5,7-dichloroquinolin-8-yl tert-butyl carbonate intermediate 10.

Finally, EDC coupling of $\mathbf{1 0}$ with indole-2-carboxylic acids $\mathbf{5 a}$ or $\mathbf{5 b}$ afforded the Boc-protected amide intermediates 11a and 11b. Boc-deprotection of $11 \mathbf{a}$ and $\mathbf{1 1 b}$ was carried out with trifluoroacetic acid in dichloromethane at room temperature to afford 12a and $\mathbf{1 2} \mathbf{b}$, respectively (Scheme 3).

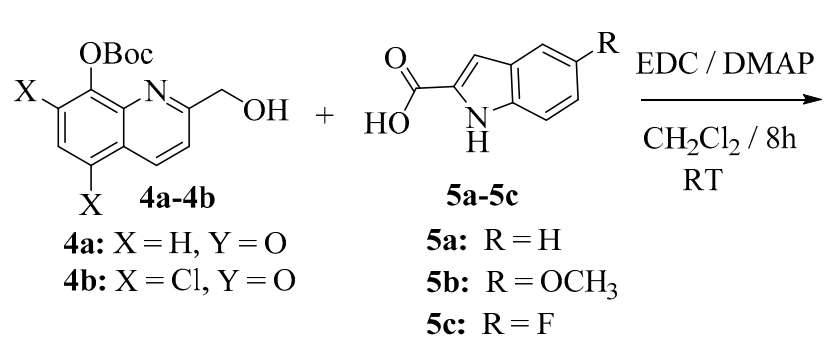<smiles>[R]c1ccc2[nH]c(C(=O)OCc3ccc4c([X])cc([X])c(OC([R])(C)O)c4n3)cc2c1</smiles>

6a: $\mathrm{X}=\mathrm{H} ; \mathrm{R}=\mathrm{H}$

6b: $\mathrm{X}=\mathrm{Cl} ; \mathrm{R}=\mathrm{H}$

6c: $\mathrm{X}=\mathrm{H} ; \mathrm{R}=\mathrm{OCH}_{3}$

6d: $\mathrm{X}=\mathrm{H} ; \mathrm{R}=\mathrm{F}$

6e: $\mathrm{X}=\mathrm{Cl} ; \mathrm{R}=\mathrm{F}$
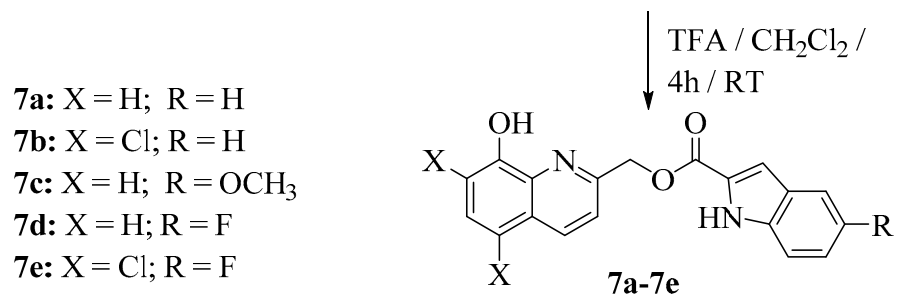

Scheme 2. Synthesis of (8-hydroxyquinolin-2-yl)methyl 1H-indole-2-carboxylate analogs 7a-7e.

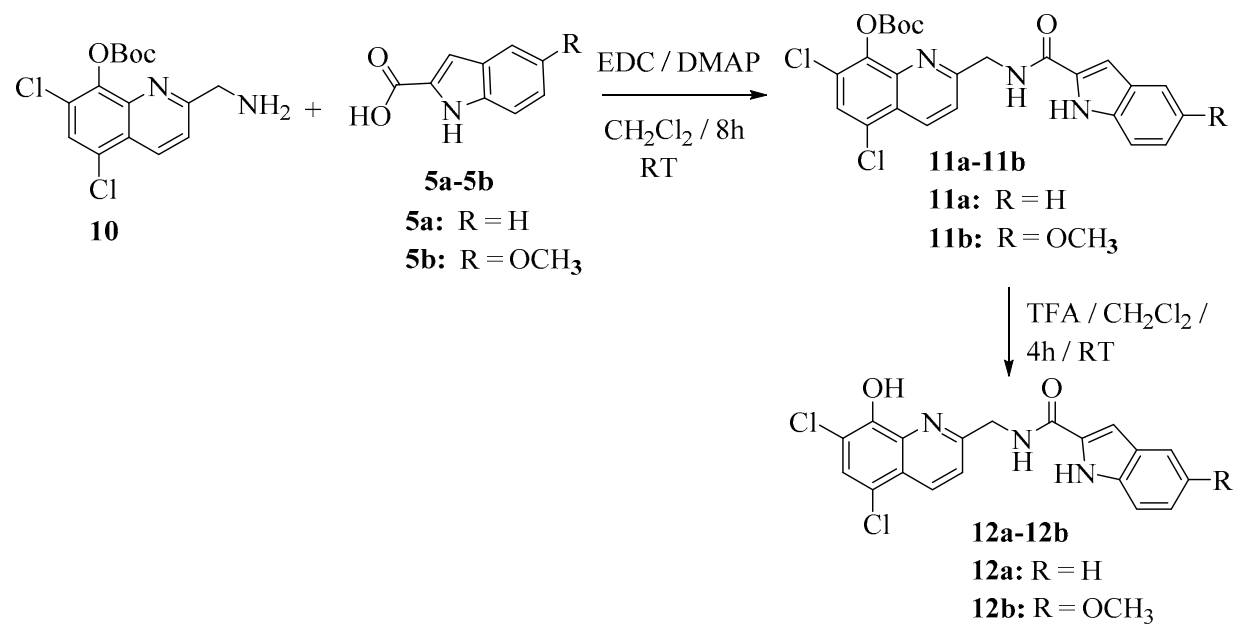

Scheme 3. Synthesis of $N$-((5,7-dichloro-8-hydroxyquinolin-2-yl)methyl)-1H-indole-2-carboxamide analogs (12a and 12b).

For the synthesis of hybrid (8-hydroxyquinolin-2-yl)methyl-4-(1H-indole-2-carbonyl)piperazine1-carboxylates $\mathbf{1 8 a - 1 8 h}$, initially we synthesized 8-(tert-butoxycarbonyloxyquinolin-2-yl)methyl 
1H-1,2,4-triazole-1- carboxylate intermediates $\mathbf{1 4 a - 1 4 c}$ by reacting tert-butyl (2-(hydroxymethyl)quinolin-8-yl) carbonates 4a-4c with di-(1H-1,2,4-triazol-1-yl)methanone (13, CDT) in dichloromethane at room temperature. Compounds 14a-14c were then each reacted with piperazine (15) in dichloromethane at room temperature to afford the corresponding piperazine-1-carboxylates 16a-16c, which were subjected to EDC coupling with indole-2-carboxylic acids $\mathbf{5 a - 5 c}$ to afford the Boc-protected intermediates 17a-17h. Subsequent deprotection of 17a-17h with trifluoroacetic acid in dichloromethane at room temperature over $4 \mathrm{~h}$ afforded the desired series of (8-hydroxyquinolin-2-yl)methyl-4-(1H-indole-2-carbonyl)piperazine-1-carboxylates 18a-18h in 75-90\% yields (Scheme 4). Structural confirmation of all the above intermediates and final synthetic products was obtained from ${ }^{1} \mathrm{H}-\mathrm{NMR},{ }^{13} \mathrm{C}-\mathrm{NMR}$, and HR-MS analysis (See Supplementary Materials).

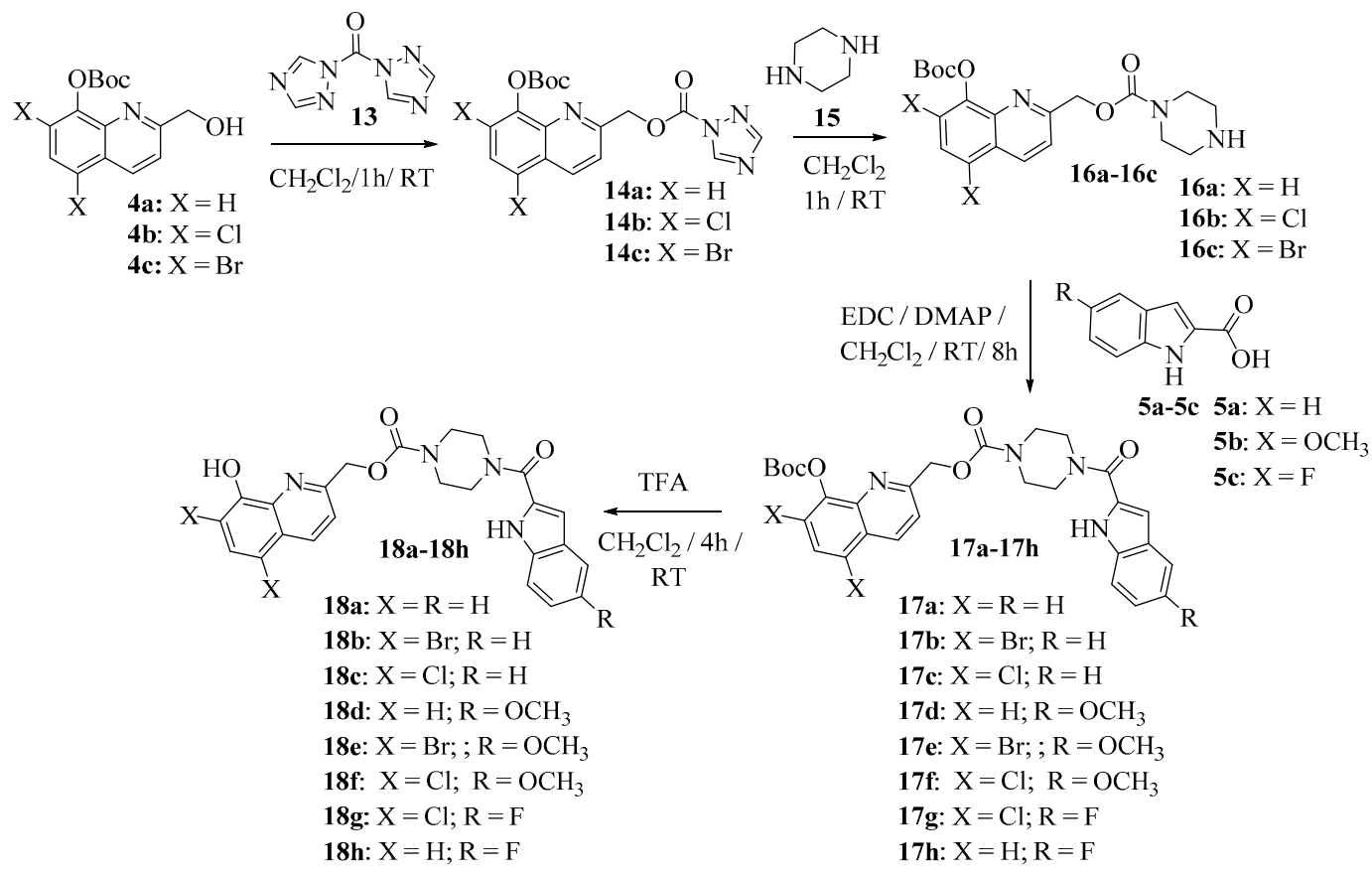

Scheme 4. Synthesis of (8-hydroxyquinolin-2-yl)methyl-4-(1H-indole-2-carbonyl)piperazine-1carboxylate analogs $\mathbf{1 8 a - 1 8 h}$.

\section{Results and Discussion}

The novel hybrid 8-hydroxyquinoline-indole derivatives, 7a-7e, 12a, 12b, and the (8-hydroxyquinolin-2-yl)methyl-4-(1H-indole-2-carbonyl)piperazine-1-carboxylate analogs 18a-18h were evaluated for inhibitory activity against self-induced $A \beta_{1-42}$ aggregation at five different concentrations $(0.3,1.0,3,9$ and $27 \mu \mathrm{M})$ with $25 \mu \mathrm{M} \mathrm{A} \beta_{1-42}$, utilizing a thioflavin $\mathrm{T}$ (ThT) fluorescence assay with clioquinol, 1 as a positive control (Figure 3). In the absence of inhibitor, the self-induced $\mathrm{A} \beta_{1-42}$ aggregation ThT fluorescence was recorded as 115 arbitrary units (a.u.). The self-induced $\mathrm{A} \beta_{1-42}$ aggregation results for all the above synthetic analogs from the ThT fluorescence assay are shown in Table 1. The results indicate that analogs lacking a piperazino bridging moiety in their structure (i.e., 7a-7e and 12a-12b) were found to be either weak inhibitors or inactive against self-induced $\mathrm{A} \beta_{1-42}$ aggregation. Of the piperazino-containing compounds $\mathbf{1 8 a} \mathbf{- 1 8 h}$, five analogs exhibited $\mathrm{EC}_{50}$ values $>3 \mu \mathrm{M}$. 8-Hydroxyquinolin-2-yl compounds containing the piperazine bridge linked to indole (18c), or 5-methoxy indole (18d and 18f) $\left(\mathrm{EC}_{50}=1.72,1.48\right.$ and $1.08 \mu \mathrm{M}$, respectively) were the most potent inhibitors of self-induced $\mathrm{A} \beta_{1-42}$ and were superior to both clioquinol $\left(1, \mathrm{EC}_{50}=9.95 \mu \mathrm{M}\right)$ and $1 H$-indole-2-carboxylic acid $\left(5 \mathrm{a}, \mathrm{EC}_{50}>20 \mu \mathrm{M}\right)$. The structure activity study (SAR) revealed that incorporation of the piperazino bridging moiety between a 5-methoxy indole group and a 5,7-dichloro-8-hydroxyquinoline group affords the most potent compound, 18f, which exhibited a 10-fold improvement in inhibitory potency over $\mathbf{1}$. 

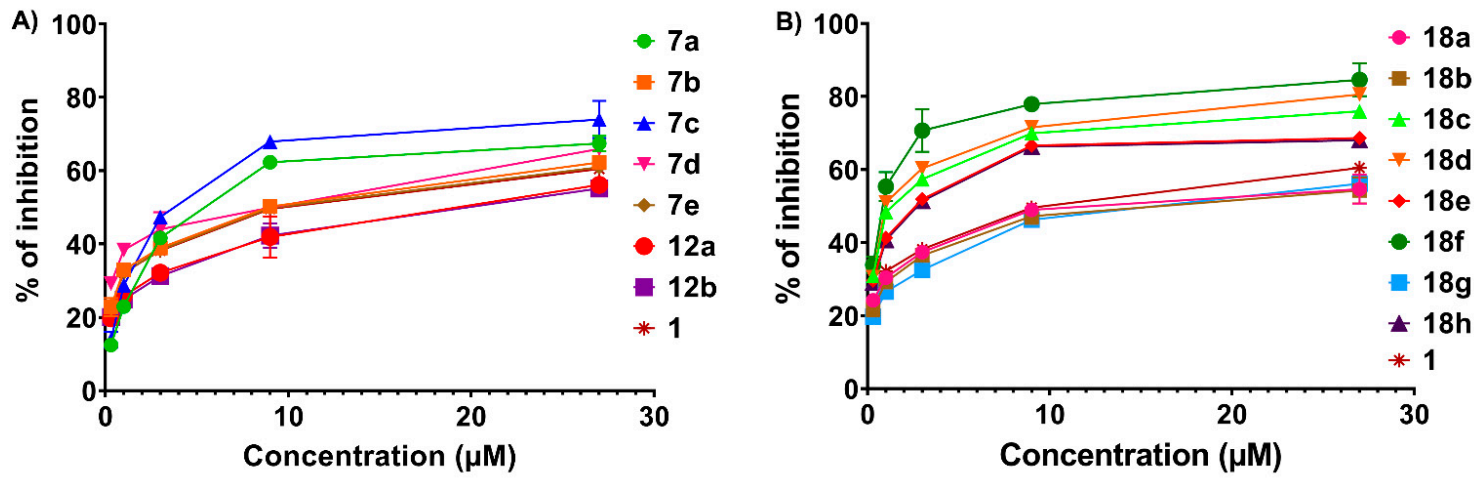

Figure 3. Dose-response curves of (A) compounds 7a-7e, 12a-12b and $\mathbf{1} ;(B)$ compounds $\mathbf{1 8 a}-\mathbf{1 8 h}$ and 1 against self-induced $A \beta_{1-42}$ aggregation.

Table 1. $\mathrm{EC}_{50}(\mu \mathrm{M})$ values of compound 1, and hybrid 8-hydroxyquinoline-indole derivatives 7a-7e, 12a-12b and 18a-18h against self-induced $A \beta_{1-42}$ aggregation in thioflavin $T$ (ThT)-fluorescence assays.

\begin{tabular}{ccccccccc}
\hline Compd. & $\mathbf{1}$ & $\mathbf{7 a}$ & $\mathbf{7 b}$ & $\mathbf{7 c}$ & $\mathbf{7 d}$ & $\mathbf{7 e}$ & $\mathbf{1 2 a}$ & $\mathbf{1 2 b}$ \\
\hline $\mathrm{A} \beta_{1-42}$ & 9.95 & 4.26 & 9.28 & 3.22 & 6.34 & 9.52 & $>10$ & $>10$ \\
\hline Compd. & $\mathbf{1 8 a}$ & $\mathbf{1 8 b}$ & $\mathbf{1 8 c}$ & $\mathbf{1 8 d}$ & $\mathbf{1 8 e}$ & $\mathbf{1 8 f}$ & $\mathbf{1 8 g}$ & $\mathbf{1 8 h}$ \\
\hline $\mathrm{A} \beta_{1-42}$ & $>10$ & $>10$ & 1.72 & 1.48 & 2.49 & 1.08 & $>10$ & 2.58 \\
\hline
\end{tabular}

Analogs 18c, 18d, and 18f, showed potent self-induced $A \beta_{1-42}$ aggregation $(<2 \mu \mathrm{M})$ and were selected for further investigation for inhibition of $\mathrm{Cu}^{2+}$ - and $\mathrm{Zn}^{2+}$-induced $\mathrm{A} \beta_{1-42}$ aggregation. Metal ions such as $\mathrm{Cu}^{2+}$ and $\mathrm{Zn}^{2+}$ can react with $\mathrm{A} \beta$ to form $\mathrm{A} \beta$ oligomers, and then eventually to form $\mathrm{A} \beta$ amyloid plaques $[8,14]$. Due to their inhibitory activity against $A \beta_{1-42}, \mathbf{1 8 c} \mathbf{1 8 d}$, and $\mathbf{1 8 f}$ were expected to decrease metal ion-induced $\mathrm{A} \beta_{1-42}$ aggregation.

Initially, $\mathrm{CuSO}_{4}$ or $\mathrm{ZnCl}_{2}$ was added to $\mathrm{A} \beta_{1-42}$ peptides at room temperature and the mixture incubated with or without drugs for $24 \mathrm{~h}$ at $37^{\circ} \mathrm{C}$. The fluorescence intensity of $\mathrm{A} \beta_{1-42}$ peptide alone was designated as $100 \%$. The fluorescence intensity of $\mathrm{A} \beta_{1-42}$ peptide after treatment with $\mathrm{Cu}^{2+}$ was $135.1 \%$ and after treatment with $\mathrm{Zn}^{2+}$ was $129.3 \%$ compared to $\mathrm{A} \beta_{1-42}$ alone (Figure $4 \mathrm{~A}, \mathrm{~B}$ ), indicating that both $\mathrm{Cu}^{2+}$ and $\mathrm{Zn}^{2+}$ ions significantly enhanced $\mathrm{A} \beta_{1-42}$ aggregation.
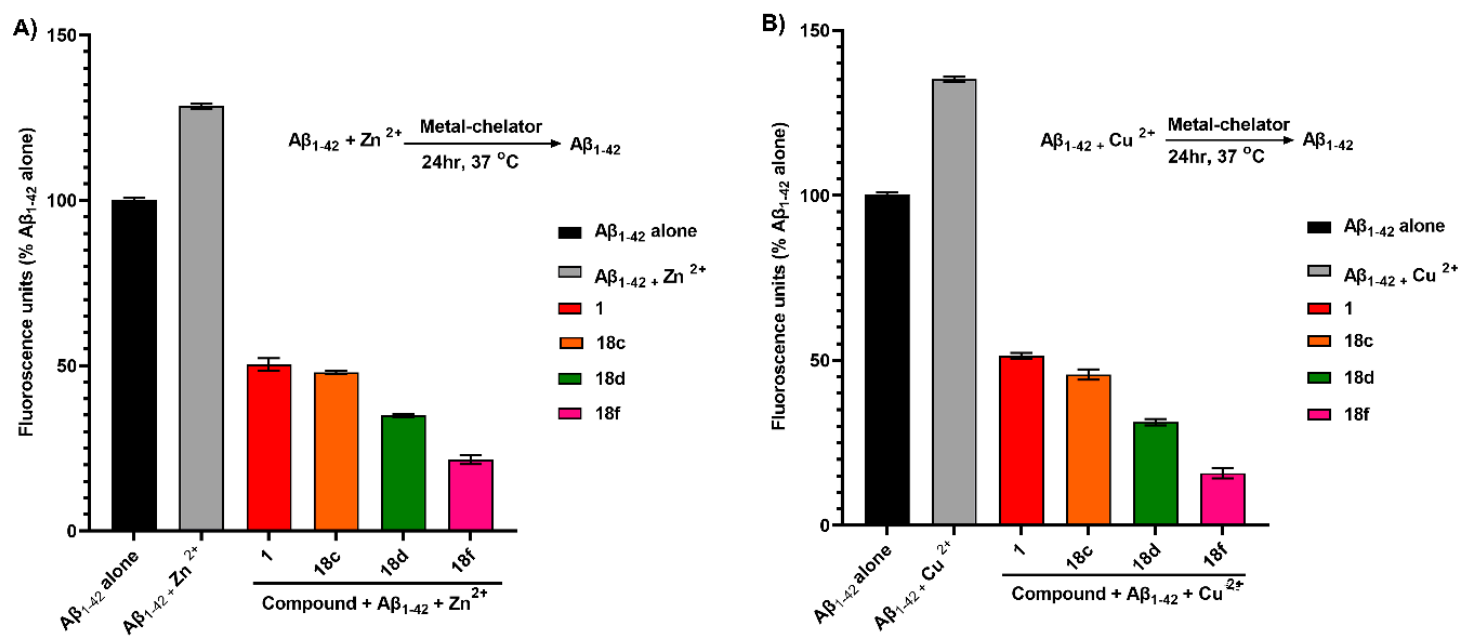

Figure 4. Effect of (A) $\mathrm{Zn}^{2+}$ - induced and (B) $\mathrm{Cu}^{2+}$-induced $\mathrm{A} \beta_{1-42}$ aggregation in the presence clioquinol (1), 18c, 18d, and $\mathbf{1 8 f}$ at $50 \mu \mathrm{M}$. Data shown are presented as the mean $\pm \mathrm{SD}$ of three independent experiments. 
In contrast, the fluorescence produced by $\mathrm{A} \beta_{1-42}$ treated with $\mathrm{Cu}^{2+}$ or $\mathrm{Zn}^{2+}$ ions in the presence of $\mathbf{1 8 c}, \mathbf{1 8 d}$, and $\mathbf{1 8 f}$ dramatically decreased (Figure 4), indicating inhibition of metal ion-induced $\mathrm{A} \beta_{1-42}$ aggregation (i.e., $18 \mathrm{c}, 76.6 \%$ decrease $\left(\mathrm{Cu}^{2+}\right)$ and $70.3 \%$ decrease $\left(\mathrm{Zn}^{2+}\right) ; \mathbf{1 8 d}, 66.1 \%$ decrease $\left(\mathrm{Cu}^{2+}\right)$ and $59.3 \%$ decrease $\left(\mathrm{Zn}^{2+}\right) ; \mathbf{1 8 f}, 88.3 \%$ decrease $\left(\mathrm{Cu}^{2+}\right)$ and $82.3 \%$ decrease $\left(\mathrm{Zn}^{2+}\right)$; and for comparison compound $1,62.5 \%$ decrease $\left(\mathrm{Cu}^{2+}\right)$ and $57.2 \%$ decrease $\left.\left(\mathrm{Zn}^{2+}\right)\right)$. These results show that $\mathbf{1 8 f}$ exhibited significantly greater inhibitory activity in $\mathrm{Cu}^{2+}$ - and $\mathrm{Zn}^{2+}$-induced $\mathrm{A} \beta_{1-42}$ aggregation than compound 1 .

Based on the above results from self-induced $A \beta_{1-42}$ aggregation and metal-induced $A \beta_{1-42}$ aggregation studies, the most potent compounds $18 \mathrm{f}$ was selected for further investigation into its ability to chelate metal ions such as $\mathrm{Cu}^{2+}, \mathrm{Zn}^{2+}$, and $\mathrm{Fe}^{2+}$ using UV-vis spectroscopy at wavelengths ranging from 200 to $500 \mathrm{~nm}$. Compound $18 \mathrm{f}(50 \mu \mathrm{M})$ was treated with $50 \mu \mathrm{M}$ concentrations of $\mathrm{CuSO}_{4}$, $\mathrm{ZnCl}_{2}$, or $\mathrm{FeSO}_{4}$ for 30 min in HEPES buffer at room temperature, and displayed maximum absorption wavelength shifts from 252 to 274,269 and $255 \mathrm{~nm}$ in the presence of $\mathrm{Cu}^{2+}, \mathrm{Zn}^{2+}$, and $\mathrm{Fe}^{2+}$, respectively (Figure 5). These wavelength shifts are indicative of the formation of $18 \mathrm{f}-\mathrm{Cu}^{2+}, \mathbf{1 8 f}-\mathrm{Zn}^{2+}$, and $\mathbf{1 8 f}-\mathrm{Fe}^{+2}$ and show that $\mathrm{Zn}^{2+}$ and $\mathrm{Cu}^{2+}$ undergo significant chelation with compound 18f. The spectrum of $18 \mathrm{f}-\mathrm{Fe}^{2+}$ showed only a moderate increase in wavelength. Furthermore, the stoichiometry of formation of metal complexes $\mathbf{1 8 f}-\mathrm{Cu}^{2+}$ and $\mathbf{1 8 f}-\mathrm{Zn}^{2+}$ was also determined by using Job's method (Figure 6) [36]. The isosbestic points shown in Figure 6A,B at 0.6 and 0.5 imply a stoichiometry of $1.5: 1$ for $\mathbf{1 8 f}-\mathrm{Cu}^{2+}$ and $1: 1$ for $\mathbf{1 8 f}-\mathrm{Zn}^{2+}$.

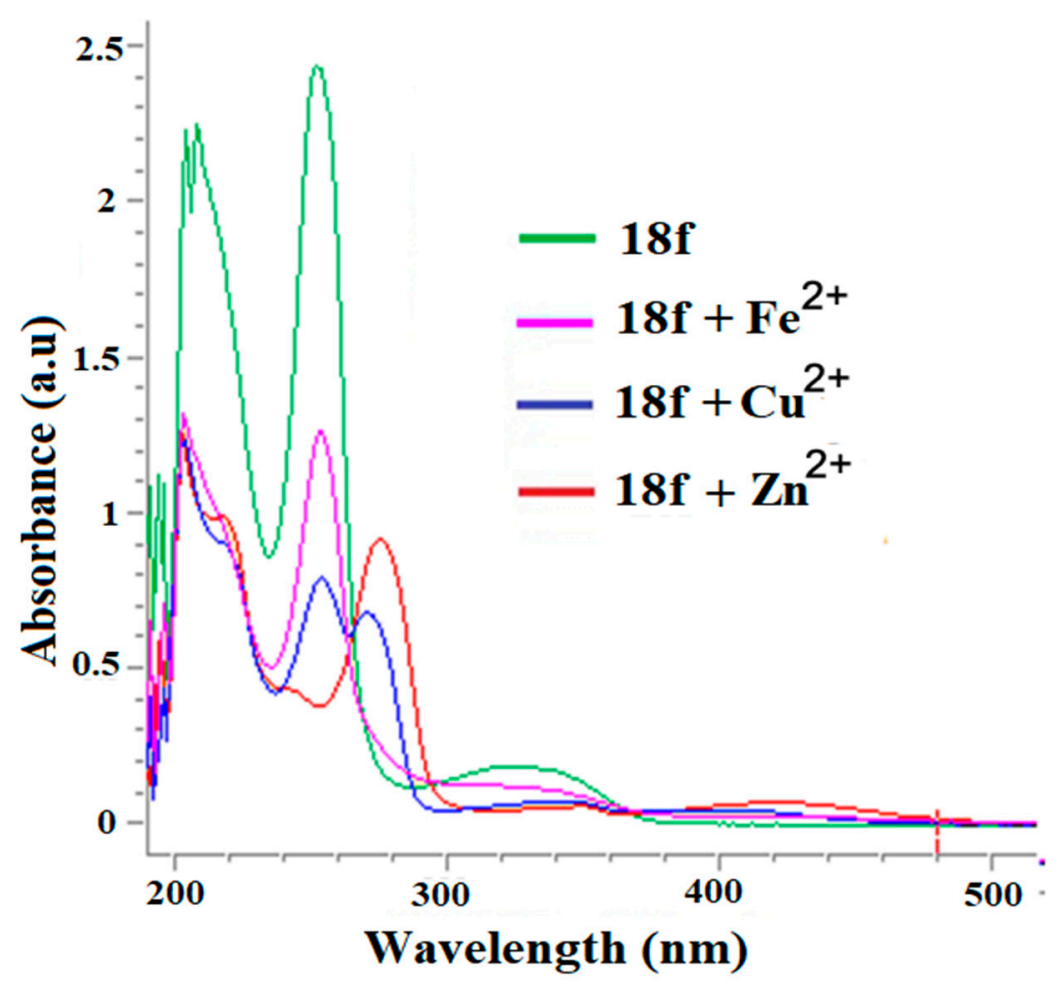

Figure 5. UV-absorbance spectra of compound $18 \mathrm{f}(50 \mu \mathrm{M})$ in the presence of $\mathrm{Cu}^{2+}, \mathrm{Zn}^{2+}$, or Fe${ }^{2+}$ (each at $50 \mu \mathrm{M})$ in buffer $(20 \mathrm{mM}$ HEPES, $150 \mathrm{mM} \mathrm{NaCl}$; $\mathrm{pH}=7.4)$. 18f displayed maximum absorption wavelength shifts from 252 to 274,269 and $255 \mathrm{~nm}$ in the presence of $\mathrm{Cu}^{2+}, \mathrm{Zn}^{2+}$, and $\mathrm{Fe}^{2+}$, respectively.

Copper and zinc dysregulation in the brain is considered to arise as a consequence of age-associated neurodegenerative disease such as Alzheimer's disease. Zinc has also been shown to play an important role in pre- and post-synaptic responses [37]. Our drug design approach is to target dysregulation of metal homeostasis and protein aggregation. Dysregulation of metal ions is implicated in the elevated formation of reactive oxygen species and in susceptibility to oxidative stress. These metal ions were shown to interact with protein aggregation seed proteins such as tau and $A \beta_{1-42}$, increasing misfolding 
and promoting protein aggregation. The 8-hydroxyquinoline compound, PBT2, has been shown to influence trans-synaptic effects of copper and zinc ions in a cell culture model and has been considered as a treatment for AD [38]. PBT2 (2) was also shown to induce amyloid degradation by inhibiting glycogen synthase kinase-3 activity via phosphorylation [38].

A) at $274 \mathrm{~nm}$

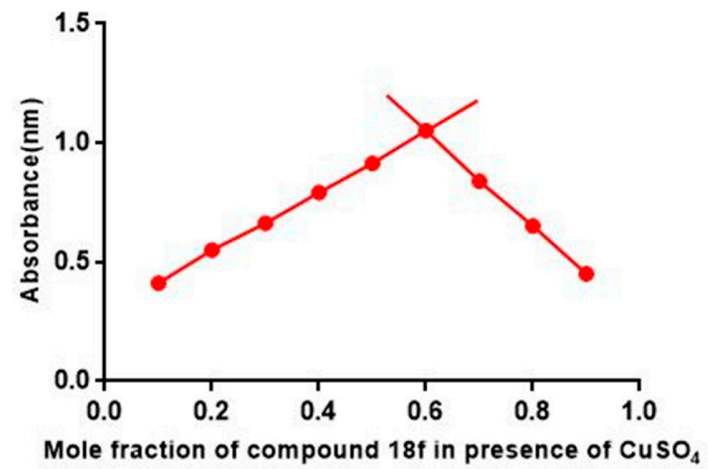

B) at $271 \mathrm{~nm}$

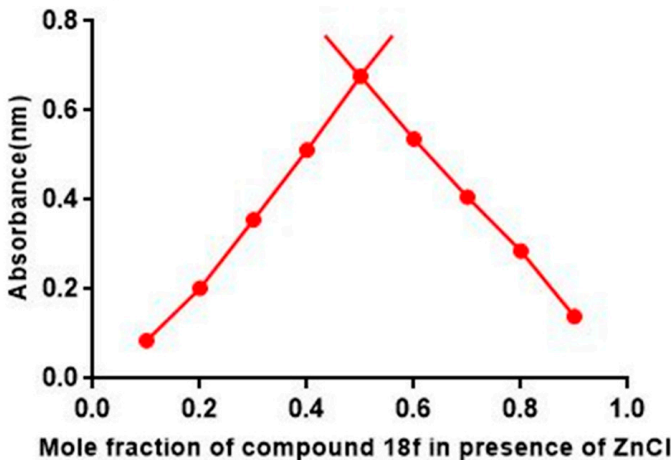

Figure 6. Determination of the stoichiometry of (A) 18f- $\mathrm{Cu}^{2+}$ complex and (B) the $\mathbf{1 8 f}-\mathrm{Zn}^{2+}$ complex by Job's method [34].

In our study, we have shown that restoring metal homeostasis by treatment with hybrid 8-hydroxyquinoline-indole analogs reduces tau- and amyloid-mediated protein aggregation, and their associated neurotoxicity. Analogs 7a-7d, 18c-18f, and 18h were evaluated for their ability to reduce protein aggregation in HEK-tau cells. HEK-tau cells were exposed to the above $A \beta_{1-42}$ aggregation inhibitors and parent drug clioquinol (1) at $1 \mu \mathrm{M}$ for $48 \mathrm{~h}$ at $37^{\circ} \mathrm{C}$. Cells were assessed for amyloid deposits by staining with $0.1 \% w / v$ thioflavin $\mathrm{T}$, counterstaining nuclei with DAPI, and mean ThT fluorescence signal per nucleus was calculated over multiple fields [39]. All the analogs reduced fluorescence intensity (indicative of protein aggregation) by $26-62 \%(P<0.001$ by 2 -tailed $t$-test). Among these analogs, compounds $\mathbf{7 b - 7 d , 1 8 c}$, and $\mathbf{1 8 f}$ were the most effective as protein aggregation inhibitors in HEK-tau cells, and were more potent than clioquinol (1) (Figure 7A,B).
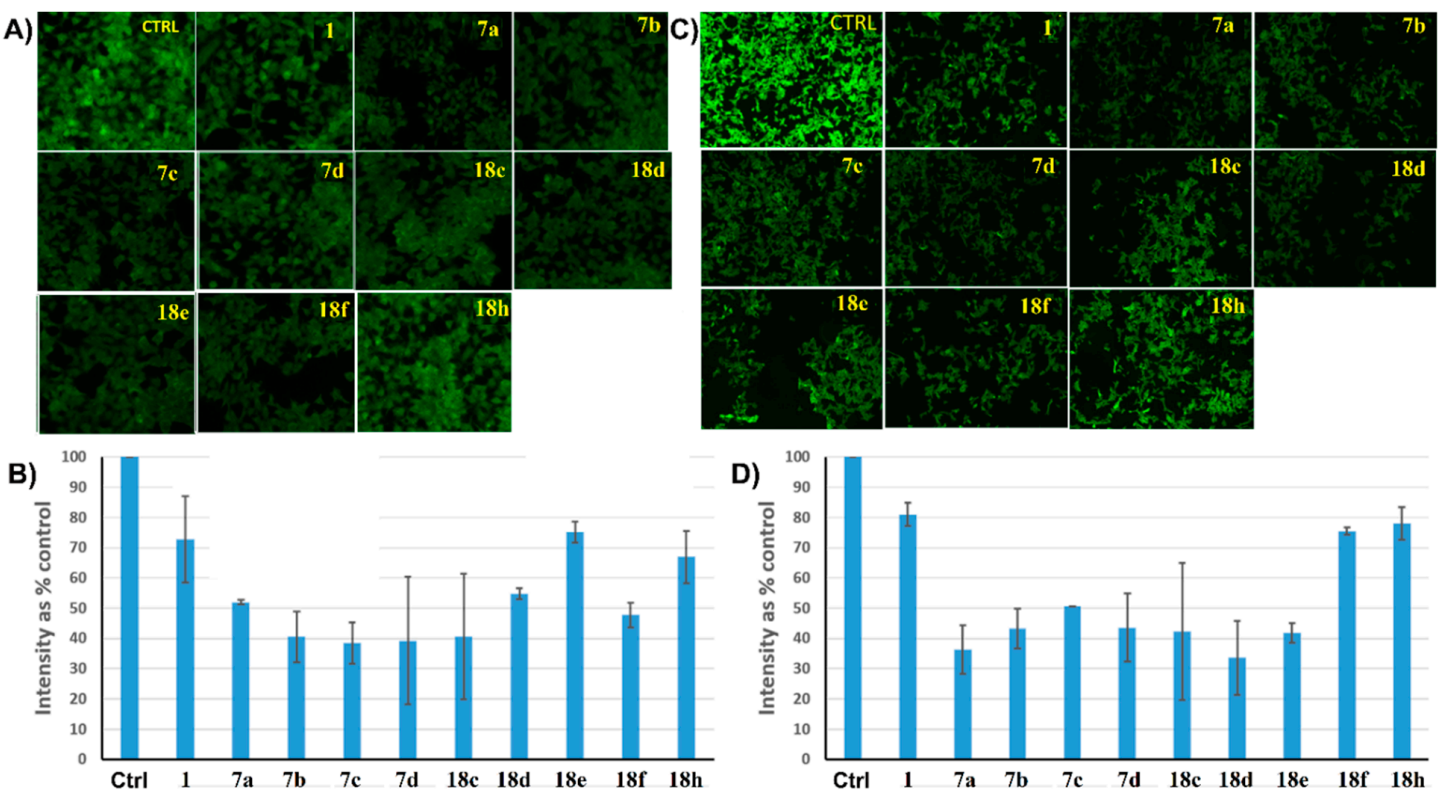

Figure 7. Amyloid-like aggregate intensity reduction by several analogs of hybrid 8-hydroxy

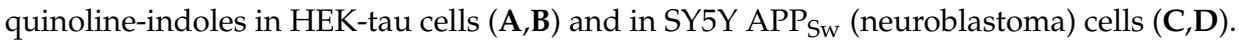




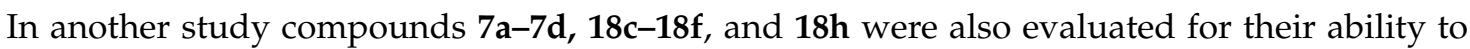
reduce protein aggregation in SY5Y-APP ${ }_{S w}$ cells. SY5Y-APP ${ }_{S w}$ cells were exposed to the above protein aggregation inhibitors and parent compound 1 at $1 \mu \mathrm{M}$ for $48 \mathrm{~h}$ at $37^{\circ} \mathrm{C}$. Cells were assessed for amyloid deposits by staining with $0.1 \%$ w $/ v$ ThT, counterstaining nuclei with DAPI, and mean ThT fluorescence signal per nucleus calculated over multiple fields. All the analogs reduced fluorescence intensity (indicative of protein aggregation) by $22-67 \%(P<0.001$ by 2 -tailed $t$-test). Analogs $7 \mathbf{a}$ and 18d were the most effective in SY5Y-APP ${ }_{S w}$ cells and were more potent than the parent compound, clioquinol (1) (Figure 7C,D). Thioflavin-T fluorescence assays for in vitro amyloid aggregation and cell culture models of amyloid aggregation overlap but are not identical. This is due to the fact that thioflavin in cell-culture stains not just amyloid aggregates but also other amyloid-like fibrillar structures. Another important difference is that in vitro aggregation is assessed after $24 \mathrm{~h}$, whereas aggregation in cell culture is assessed after $48 \mathrm{~h}$.

The binding interactions of the active compounds $\mathbf{1 8 d}$ and $\mathbf{1 8 f}$ were also investigated utilizing a crystal structure of the target $A \beta_{1-42}$ peptide (PDB code: 1IYT) [40] employing Schrodinger Maestro 11.4 software (Figure 8) [41]. For analogue 18d, the quinoline ester carbonyl group of this hybrid molecule is involved in a hydrogen bonding interaction with Lys16 at a distance of $3.12 \mathrm{~A}^{\circ}$ units and the 8-hydroxyquinoline moiety is involved in a $\pi-\pi$ stacking interaction with residue Phe20; this is similar to that observed with the deoxyvasicinone-donepezil hybrid molecule binding region on $\mathrm{A} \beta_{1-42}$ reported in the literature [41]. In addition, the quinolone and indole ring systems of compound $\mathbf{1 8 d}$ are involved in $\pi$-cation interactions with Lys16. With the potent analog $\mathbf{1 8 f}$, the hydroxyl group of the 8-hydroxyquinoline moiety is involved in a hydrogen bonding interaction with the His13 residue at $2.17 \mathrm{~A}^{\mathrm{o}}$ units, and the 8-hydroxyquinoline moiety of $\mathbf{1 8 f}$ is also involved in a $\pi-\pi$ stacking interaction with Phe20, similar to the binding mode of compound 18d. In addition, the quinoline ring system of $\mathbf{1 8 f}$ is involved in a $\pi$-cation interaction with Lys16. These docking results indicate that the effective inhibition of both self-induced and metal ion-induced $A \beta_{1-42}$ aggregation by $\mathbf{1 8 d}$ and $\mathbf{1 8 f}$ may be due to hydrogen bonding interactions, $\pi-\pi$ stacking interactions, and $\pi$-cation interactions of these molecules. Of particular interest is the interaction the most potent compound 18f with the His13 residue on the $A \beta_{1-42}$ peptide. His13 has been implicated in the binding of metal ions with $A \beta_{1-42}$ (17-21); thus, $18 f$ may compete with metal ions for this binding site on $A \beta_{1-42}$, thereby inhibiting metal ion induction of $A \beta_{1-42}$ aggregation.
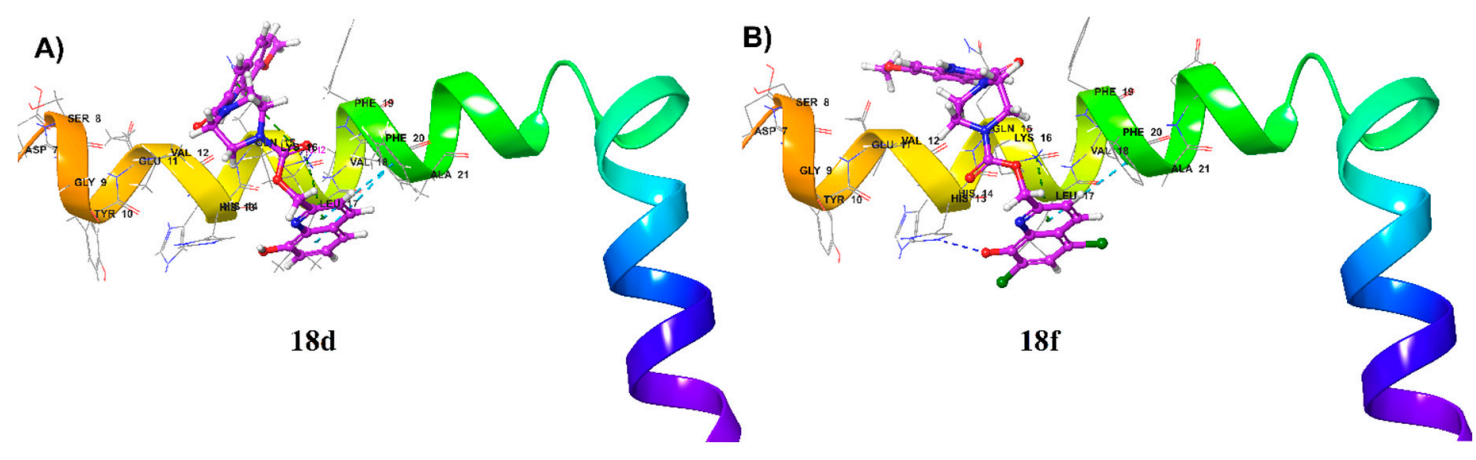

Figure 8. Proposed binding modes of $(\mathbf{A})$ compound $\mathbf{1 8 d}$ and (B) $\mathbf{1 8 f}$ with $A \beta_{1-42}$ peptide.

In summary, a series of hybrid 8-hydroxyquinoline-indole derivatives $\mathbf{7 a - 7 e}, \mathbf{1 2 a}-\mathbf{1 2} \mathbf{b}$, and 18a-18h have been synthesized and evaluated as inhibitors of $A \beta_{1-42}$ self-aggregation and metal chelation-induced aggregation, and have also been evaluated against HEK-tau and SY5Y-APP ${ }_{S w}$ cells to determine their effect on cellular protein aggregation. In vitro studies showed that hybrid 8-hydroxyquinoline-indole analogs lacking the piperazine bridging unit (i.e., compounds 7a-7e and 12a-12b) exhibited poor-to-moderate inhibitory activities against $A \beta_{1-42}$ peptide self-aggregation. However, the majority of the hybrid 8-hydroxyquinoline-indole compounds incorporating the piperazine bridge unit (i.e., 18c-18f, and 18h) were potent inhibitors against $A \beta_{1-42}$ self-aggregation. 
Analogue $\mathbf{1 8 f}$ was the most potent inhibitor of $A \beta_{1-42}$ aggregation in both self-induced and metal chelation-induced assays, and in protein aggregation assays in HEK-tau cells. Compound $\mathbf{1 8 f}$ afforded $82.3 \%$ and $88.3 \%$ inhibition against $\mathrm{Cu}^{2+}$-induced and $\mathrm{Zn}^{2+}$-induced $\mathrm{A} \beta_{1-42}$ aggregation assays, and was also shown to be a chelator of $\mathrm{Cu}^{2+}, \mathrm{Zn}^{2+}$, and $\mathrm{Fe}^{2+}$ ions in physiological buffer solutions. Molecular docking studies with $\mathbf{1 8 f}$ showed that this molecule has the potential to interact with the His13 residue on $A \beta_{1-42}$ peptide, which suggests that its potent anti-aggregation properties may also be due in part to its ability to competitively inhibit the binding of metal ions that interact with this site to induce $A \beta_{1-42}$ aggregation. Thus, the present study has identified 18f, an analog that incorporates a piperazine bridging group between a 5-methoxyindole moiety and a 5,7-dichloro-8-hydroxyquinoline moiety, as the most potent $A \beta_{1-42}$ aggregation inhibitor; this analog exhibited a 10 -fold improvement in inhibitory potency over clioquinol (1) as an inhibitor of $A \beta_{1-42}$ self-aggregation. We consider $\mathbf{1 8 f}$ to be a lead compound worthy of further structural optimization and preclinical development as a treatment for AD.

\section{Experimental Section}

\subsection{Chemistry}

All reagents, solvents, and chemicals utilized in the synthesis of the hybrid 8-hydroxyquinoline-indole analogs were purchased from Oakwood Chemicals Fisher Scientific and Adooq Bioscience. ${ }^{1} \mathrm{H}$ and ${ }^{13} \mathrm{C}-\mathrm{NMR}$ spectra were recorded on a Varian $400 \mathrm{MHz}$ spectrometer equipped with a Linux workstation running on vNMRj software. Spectral analyses were carried out in $\mathrm{CDCl}_{3}$ or DMSO- $d_{6}$ for both ${ }^{1} \mathrm{H}$ and ${ }^{13} \mathrm{C}$ spectra. Chemical shifts were measured in $\delta$ parts per million $($ ppm) and coupling constants $(J)$ were measured in hertz $(\mathrm{Hz})$. High-resolution mass spectra (HR-MS) were recorded on an Agilent 6545 ESI/APCI TOF MS. Thin-layer chromatography (TLC) was carried out on pre-coated silica gel glass plates (F254 Merck).

\subsection{Experimental Procedure for the Synthesis of Hybrid 8-Hydroxyquinoline-Indole Analogs}

Synthesis of (8-hydroxyquinolin-2-yl)methyl-1H-indole-2-carboxylate hybrid analogs 7a-7e

To a stirred solution of an appropriate indole-2-carboxylic acid (5a-5c) (0.15 mmol) in dry dichloromethane $(5 \mathrm{~mL})$ under an argon atmosphere at $0{ }^{\circ} \mathrm{C}$ was added 1-ethyl-3-(3-dimethylamino propyl)carbodiimide (EDCI, $0.181 \mathrm{mmol}$ ), and the mixture allowed to stir for $15 \mathrm{~min}$. A catalytic amount of 4-dimethylaminopyridine (DMAP, $0.045 \mathrm{mmol}$ ) was then added, followed by addition of an appropriate tert-butyl (2-(hydroxymethyl)quinolin-8-yl) carbonate (4a-4b) (0.151 mmol) in dry dichloromethane $(3 \mathrm{~mL})$ at $0{ }^{\circ} \mathrm{C}$. The resulting mixture was stirred for $8 \mathrm{~h}$ at room temperature. After completion of the reaction (monitored by TLC), the reaction mixture was washed with water (10 $\mathrm{mL})$, and the dichloromethane layer separated, dried over anhydrous sodium sulfate, filtered, concentrated, and purified by silica gel column chromatography using 2-5\% methanolic dichloromethane as eluent to afford the corresponding Boc-protected 8-hydroxyquinoline-indole derivatives (6a-6e).

The above Boc-protected 8-hydroxyquinoline-indole derivatives (6a-6e) were each dissolved in a mixture of DCM $(10 \mathrm{~mL})$ and TFA $(1.0 \mathrm{~mL})$ and stirred for $6 \mathrm{~h}$ until the Boc-deprotection was completed. A saturated $\mathrm{NaHCO}_{3}$ solution $(20 \mathrm{~mL})$ was then added and the resulting mixture was extracted with dichloromethane. The organic layer was separated and washed with water, followed by brine solution, dried over anhydrous $\mathrm{Na}_{2} \mathrm{SO}_{4}$, and concentrated to afford the appropriate hybrid 8-hydroxyquinoline indole derivatives (7a-7e).

(8-Hydroxyquinolin-2-yl)methyl-1H-indole-2-carboxylate (7a): ${ }^{1} \mathrm{H}-\mathrm{NMR}\left(400 \mathrm{MHz}, \mathrm{DMSO}-d_{6}\right): \delta 12.00(\mathrm{~s}$, $1 \mathrm{H}), 9.67(\mathrm{~s}, 1 \mathrm{H}), 8.38(\mathrm{~d}, J=8.4 \mathrm{~Hz}, 1 \mathrm{H}), 7.76-63(\mathrm{~m}, 2 \mathrm{H}), 7.52-7.37(\mathrm{~m}, 3 \mathrm{H}), 7.35-7.22(\mathrm{~m}, 2 \mathrm{H}), 7.13-7.07$ $(\mathrm{m}, 2 \mathrm{H}), 5.64(\mathrm{~s}, 2 \mathrm{H}) \mathrm{ppm} .{ }^{13} \mathrm{C}-\mathrm{NMR}\left(100 \mathrm{MHz}, \mathrm{DMSO}-d_{6}\right): \delta 161.44,154.70,153.40,138.08,138.01$, 137.56, 128.57, 127.99, 127.16, 127.14, 125.34, 122.59, 120.73, 120.35, 118.15, 113.06, 112.19, 108.99, 67.50 ppm. HR-MS (ESI) $m / z$ calcd for $\mathrm{C}_{19} \mathrm{H}_{14} \mathrm{~N}_{2} \mathrm{O}_{3}(\mathrm{M}+\mathrm{H})^{+} 319.1075$, found 319.1076 . 
(5,7-Dichloro-8-hydroxyquinolin-2-yl)methyl-1H-indole-2-carboxylate (7b): ${ }^{1} \mathrm{H}-\mathrm{NMR}\left(400 \mathrm{MHz}, \mathrm{DMSO}-\mathrm{d}_{6}\right)$ : $\delta 12.02(\mathrm{~s}, 1 \mathrm{H}), 10.67(\mathrm{~s}, 1 \mathrm{H}), 8.58(\mathrm{~d}, J=8.8 \mathrm{~Hz}, 1 \mathrm{H}), 7.91(\mathrm{~d}, J=8.8 \mathrm{~Hz}, 1 \mathrm{H}), 7.84(\mathrm{~s}, 1 \mathrm{H}), 7.7(\mathrm{~d}$, $J=8.0 \mathrm{~Hz}, 1 \mathrm{H}), 7.49(\mathrm{~d}, J=8.8 \mathrm{~Hz}, 1 \mathrm{H}), 7.33(\mathrm{~s}, 1 \mathrm{H}), 7.29(\mathrm{t}, J=7.6 \mathrm{~Hz}, 1 \mathrm{H}), 7.10(\mathrm{t}, J=7.6 \mathrm{~Hz}, 1 \mathrm{H}), 5.70$ (s, 2H) ppm. ${ }^{13} \mathrm{C}-\mathrm{NMR}\left(100 \mathrm{MHz}, \mathrm{DMSO}-d_{6}\right): \delta 161.35,156.98,149.23,138.68,138.05,134.50,128.27$, $127.15,126.97,125.42,124.61,122.62,121.61,120.77,119.58,116.56,113.06,109.14,67.02$ ppm. HR-MS (ESI) $m / z$ calcd for $\mathrm{C}_{19} \mathrm{H}_{12} \mathrm{Cl}_{2} \mathrm{~N}_{2} \mathrm{O}_{3}(\mathrm{M}+\mathrm{H})^{+}$387.0291, found 387.0296.

(8-Hydroxyquinolin-2-yl)methyl-5-methoxy-1H-indole-2-carboxylate (7c): ${ }^{1} \mathrm{H}-\mathrm{NMR}\left(400 \mathrm{MHz}, \mathrm{DMSO}-\mathrm{d}_{6}\right)$ : $\delta 11.87(\mathrm{~s}, 1 \mathrm{H}), 9.67(\mathrm{~s}, 1 \mathrm{H}), 8.38(\mathrm{~d}, J=8.4 \mathrm{~Hz}, 1 \mathrm{H}), 7.70(\mathrm{~d}, J=8.4 \mathrm{~Hz}, 1 \mathrm{H}), 7.46-7.35(\mathrm{~m}, 3 \mathrm{H}), 7.2(\mathrm{~s}$, $1 \mathrm{H}), 7.12(\mathrm{~d}, J=2.8 \mathrm{~Hz}, 2 \mathrm{H}), 6.95(\mathrm{~d}, J=8.8 \mathrm{~Hz}, 1 \mathrm{H}), 5.63(\mathrm{~s}, 2 \mathrm{H}), 3.76(\mathrm{~s}, 3 \mathrm{H}) \mathrm{ppm} .{ }^{13} \mathrm{C}-\mathrm{NMR}(100 \mathrm{MHz}$, DMSO- $\left.d_{6}\right): \delta 161.36,154.76,154.44,153.40,138.08,137.55,133.40,128.57,127.98,127.49,127.30,120.33$, $118.15,117.03,113.98,112.18,108.55,102.39,67.40,55.65$ ppm. HR-MS (ESI) $m / z$ calcd for $\mathrm{C}_{20} \mathrm{H}_{16} \mathrm{~N}_{2} \mathrm{O}_{4}$ $(\mathrm{M}+\mathrm{H})^{+} 349.1174$, found 349.1178 .

(8-Hydroxyquinolin-2-yl)methyl-5-fluoro-1H-indole-2-carboxylate (7d): ${ }^{1} \mathrm{H}-\mathrm{NMR}\left(400 \mathrm{MHz}, \mathrm{DMSO}-d_{6}\right): \delta$ $12.13(\mathrm{~s}, 1 \mathrm{H}), 9.67(\mathrm{~s}, 1 \mathrm{H}), 8.38(\mathrm{~d}, J=8.4 \mathrm{~Hz}, 1 \mathrm{H}), 7.71(\mathrm{~d}, J=8.4 \mathrm{~Hz}, 1 \mathrm{H}), 7.50-7.40(\mathrm{~m}, 4 \mathrm{H}), 7.28(\mathrm{~s}, 1 \mathrm{H})$, 7.19-7.11 (m, 2H), $5.64(\mathrm{~s}, 2 \mathrm{H}) \mathrm{ppm} .{ }^{13} \mathrm{C}-\mathrm{NMR}\left(100 \mathrm{MHz}, \mathrm{DMSO}-d_{6}\right): \delta 161.17,158.86,156.54,154.58$, $153.41,138.09,137.57,134.75,128.80,128.58,128.01,127.24,127.13,120.37,118.15,114.49,114.39,114.20$, $112.20,108.88,108.83,106.66,106.43,67.62 \mathrm{ppm}$. HR-MS (ESI) $\mathrm{m} / z$ calcd for $\mathrm{C}_{19} \mathrm{H}_{13} \mathrm{FN}_{2} \mathrm{O}_{3}(\mathrm{M}+\mathrm{H})^{+}$ 337.0969 , found 337.0978 .

(5,7-Dichloro-8-hydroxyquinolin-2-yl)methyl-5-fluoro-1H-indole-2-carboxylate (7e): ${ }^{1} \mathrm{H}-\mathrm{NMR}(400 \mathrm{MHz}$, DMSO- $\left.d_{6}\right): \delta 12.14(\mathrm{~s}, 1 \mathrm{H}), 10.64(\mathrm{~s}, 1 \mathrm{H}), 8.57(\mathrm{~d}, J=8.8 \mathrm{~Hz}, 1 \mathrm{H}), 7.91(\mathrm{~d}, J=8.8 \mathrm{~Hz}, 1 \mathrm{H}), 7.83(\mathrm{~s}, 1 \mathrm{H})$, $7.50(\mathrm{~m}, 2 \mathrm{H}), 7.30(\mathrm{~d}, J=2.0 \mathrm{~Hz}, 1 \mathrm{H}), 7.16(\mathrm{td}, J=9.2,2.4 \mathrm{~Hz}, 1 \mathrm{H}), 5.67(\mathrm{~s}, 2 \mathrm{H}) \mathrm{ppm} ;{ }^{13} \mathrm{C}-\mathrm{NMR}(100 \mathrm{MHz}$, DMSO- $\left.d_{6}\right): \delta 161.09,158.87,156.83,156.54,149.20,138.66,134.78,134.47,128.62,128.26,127.21,127.11$, $124.59,121.59,119.57,116.55,114.54,114.49,114.39,114.27,109.01,108.95,106.67,106.44,67.13$ ppm. HR-MS (ESI) $m / z$ calcd for $\mathrm{C}_{19} \mathrm{H}_{11} \mathrm{Cl}_{2} \mathrm{FN}_{2} \mathrm{O}_{3}(\mathrm{M}+\mathrm{H})^{+} 405.0187$, found 405.0199.

Synthesis of tert-butyl (5,7-dichloro-2-(iodomethyl)quinolin-8-yl) carbonate (8):

To a stirred solution of tert-butyl-(5,7-dichloro-2-(hydroxymethyl)quinolin-8-yl) carbonate $4 \mathbf{b}$ ( $1 \mathrm{mmol})$ was added triphenyl phosphine $(1.2 \mathrm{mmol})$, imidazole $(1.3 \mathrm{mmol})$ in dichloromethane, and iodine $(1.2 \mathrm{mmol})$ at room temperature. The resulting reaction mixture was stirred for $1 \mathrm{~h}$. After completion of the reaction, aqueous sodium dithionite solution was added and the resulting mixture extracted with dichloromethane, the separated organic layer was dried over $\mathrm{Na}_{2} \mathrm{SO}_{4}$ and concentrated under reduced pressure. The crude product was purified by column chromatography (silica gel, 10\% ethyl acetate in hexanes) to afford compound $\mathbf{8}$.

${ }^{1} \mathrm{H}-\mathrm{NMR}\left(400 \mathrm{MHz}, \mathrm{CDCl}_{3}\right): \delta 8.42(\mathrm{~d}, J=8.4 \mathrm{~Hz}, 1 \mathrm{H}), 7.62(\mathrm{~s}, 1 \mathrm{H}), 7.61(\mathrm{~d}, J=8.8 \mathrm{~Hz}, 1 \mathrm{H}), 4.61(\mathrm{~s}, 2 \mathrm{H})$, $1.60(\mathrm{~s}, 9 \mathrm{H}) \mathrm{ppm} .{ }^{13} \mathrm{C}-\mathrm{NMR}\left(101 \mathrm{MHz}, \mathrm{CDCl}_{3}\right): \delta 160.22,150.41,142.71,141.54,134.27,128.76,127.40$, $127.34,124.70,122.56,84.43,27.67,5.41 \mathrm{ppm}$.

Synthesis of 2-(azidomethyl)-5,7-dichloroquinolin-8-yl tert-butyl carbonate (9):

To a stirred solution of tert-butyl-(5,7-dichloro-2-(iodomethyl)quinolin-8-yl) carbonate 8 (1 mmol) in acetone was added sodium azide $(3 \mathrm{mmol})$. The resulting mixture was stirred at reflux temperature for $6 \mathrm{~h}$. After completion of the reaction, the reaction mixture was cooled to room temperature then solvent was evaporated. Water was added to the crude mass and mixture extracted with dichloromethane, the separated organic layer dried over $\mathrm{Na}_{2} \mathrm{SO}_{4}$ and concentrated under reduced pressure. The crude product was purified by column chromatography (silica gel, 1\% methanol in dichloromethane) to afford compound 9.

${ }^{1} \mathrm{H}-\mathrm{NMR}\left(\mathrm{CDCl}_{3}, 400 \mathrm{MHz}\right): \delta 8.49(\mathrm{~d}, J=8.8 \mathrm{~Hz}, 1 \mathrm{H}), 8.00(\mathrm{~s}, 1 \mathrm{H}), 7.60(\mathrm{~d}, J=8.4 \mathrm{~Hz}, 1 \mathrm{H}), 4.64(\mathrm{~s}, 2 \mathrm{H})$, 1.59 (s, 9H) ppm. ${ }^{13} \mathrm{C}-\mathrm{NMR}\left(\mathrm{CDCl}_{3}, 101 \mathrm{MHz}\right): \delta{ }^{13} \mathrm{C}-\mathrm{NMR}\left(101 \mathrm{MHz}, \mathrm{CDCl}_{3}\right): \delta 158.07,150.27,144.91$, 141.76, 137.04, 133.13, 126.94, 121.31, 118.93, 117.11, 84.41, 77.30, 76.98, 76.67, 55.60, 27.61 ppm.

Synthesis of 2-(aminomethyl)-5,7-dichloroquinolin-8-yl tert-butyl carbonate (10): 
To a stirred solution of 2-(azidomethyl)-5,7-dichloroquinolin-8-yl tert-butyl carbonate 9 (1 mmol) in $\mathrm{THF} / \mathrm{H}_{2} \mathrm{O}(3 \mathrm{~mL}, 9: 1)$ was added $\mathrm{PPh}_{3}(1.2 \mathrm{mmol})$ at room temperature. The resulting reaction mixture was stirred at $60^{\circ} \mathrm{C}$ for $12 \mathrm{~h}$. After completion of reaction, the reaction mixture was concentrated under vacuum and $1 \mathrm{M}$ aqueous $\mathrm{HCl}$ added to the residue. The mixture was stirred for $30 \mathrm{~min}$, then the mixture was filtered to get aqueous phase. The aqueous phase was basified to $\mathrm{pH} 10$ with $\mathrm{NaHCO}_{3}$ and extracted with dichloromethane. The combined organic layer was washed with brine, dried over anhydrous $\mathrm{Na}_{2} \mathrm{SO}_{4}$, and the solution was evaporated under vacuum to afford target compound 10.

${ }^{1} \mathrm{H}-\mathrm{NMR}\left(400 \mathrm{MHz}, \mathrm{CDCl}_{3}\right): \delta 8.41(\mathrm{~d}, J=8.7 \mathrm{~Hz}, 1 \mathrm{H}), 7.63(\mathrm{~s}, 1 \mathrm{H}), 7.39(\mathrm{~d}, J=8.7 \mathrm{~Hz}, 1 \mathrm{H}), 4.89(\mathrm{~s}, 2 \mathrm{H})$, $1.58(\mathrm{~s}, 9 \mathrm{H}) \mathrm{ppm} .{ }^{13} \mathrm{C}-\mathrm{NMR}\left(101 \mathrm{MHz}, \mathrm{CDCl}_{3}\right): \delta 161.16,150.50,142.37,140.93,134.02,129.02,127.64$, $127.17,125.30,119.75,84.65,77.29,77.17,76.97,76.65,64.14,27.58$ ppm.

Synthesis of $N$-((8-hydroxyquinolin-2-yl)methyl)-1H-indole-2-carboxamide hybrid analogs 12a and 12b:

To a stirred solution of indole-2-carboxylic acid $\mathbf{5 a}$ or $\mathbf{5 b}(0.15 \mathrm{mmol})$ in dry dichloromethane $(5 \mathrm{~mL})$ under an argon atmosphere at $0{ }^{\circ} \mathrm{C}$ was added EDCI $(0.181 \mathrm{mmol})$ and the mixture allowed to stir for $15 \mathrm{~min}$. A catalytic amount of DMAP $(0.045 \mathrm{mmol})$ was then added followed by addition of 2-(aminomethyl)-5,7-dichloroquinolin-8-yl tert-butyl carbonate (10) (0.151 mmol) in dry dichloromethane $(3 \mathrm{~mL})$ at $0{ }^{\circ} \mathrm{C}$, and the resulting mixture was stirred for $8 \mathrm{~h}$ at room temperature. After completion of the reaction (monitored by TLC), the reaction mixture was washed with water $(10 \mathrm{~mL})$, and the dichloromethane layer separated, dried over anhydrous sodium sulfate, filtered, concentrated, and purified by silica gel column chromatography, using 2-5\% methanolic dichloromethane as eluent, to afford the corresponding Boc-protected 8-hydroxyquinoline-indole derivatives 11a or 11b as a solid. Products were obtained in $56-74 \%$ yield.

The above Boc-protected 8-hydroxyquinoline-indole derivatives $\mathbf{1 1 a}$ and $\mathbf{1 1} \mathbf{b}$ were each dissolved in a mixture of DCM $(10 \mathrm{~mL})$ and trifluoroacetic acid (TFA, $1.0 \mathrm{~mL})$ and the resulting mixture stirred for $6 \mathrm{~h}$ until the Boc-deprotection was completed. A saturated $\mathrm{NaHCO}_{3}$ solution $(20 \mathrm{~mL})$ was then added and the resulting mixture extracted with dichloromethane. The organic layer was separated and washed with water, followed by brine solution, dried over anhydrous $\mathrm{Na}_{2} \mathrm{SO}_{4}$, and concentrated to afford the appropriate hybrid 8-hydroxyquinoline indole derivatives 12a and $\mathbf{1 2 b}$.

N-((5,7-Dichloro-8-hydroxyquinolin-2-yl)methyl)-1H-indole-2-carboxamide (12a): ${ }^{1} \mathrm{H}-\mathrm{NMR}(400 \mathrm{MHz}$, DMSO- $\left.d_{6}\right): \delta 12.01(\mathrm{~s}, 1 \mathrm{H}), 10.71(\mathrm{~s}, 1 \mathrm{H}), 10.07(\mathrm{~s}, 1 \mathrm{H}), 8.52(\mathrm{~d}, J=8.4 \mathrm{~Hz}, 1 \mathrm{H}), 8.07(\mathrm{~s}, 1 \mathrm{H}), 7.93$ $(\mathrm{d}, J=8.8 \mathrm{~Hz}, 1 \mathrm{H}), 7.70(\mathrm{~d}, J=8.0 \mathrm{~Hz}, 1 \mathrm{H}), 7.49(\mathrm{~d}, J=8.0 \mathrm{~Hz}, 1 \mathrm{H}), 7.33(\mathrm{~s}, 1 \mathrm{H}), 7.28(\mathrm{t}, J=7.6 \mathrm{~Hz}$, $1 \mathrm{H}), 7.12(\mathrm{t}, J=7.6 \mathrm{~Hz}, 1 \mathrm{H}), 5.71(\mathrm{~s}, 2 \mathrm{H}) \mathrm{ppm} ;{ }^{13} \mathrm{C}-\mathrm{NMR}\left(100 \mathrm{MHz}, \mathrm{DMSO}-\mathrm{d}_{6}\right): \delta 161.34,156.89,151.03$, $138.59,138.05,137.00,133.70,127.14,126.97,126.25,125.41,122.61,122.08,120.77,113.06,109.39,109.14$, 106.03, 66.91 ppm. HR-MS (ESI) $m / z$ calcd for $\mathrm{C}_{19} \mathrm{H}_{13} \mathrm{Cl}_{2} \mathrm{~N}_{3} \mathrm{O}_{2}(\mathrm{M}+\mathrm{H})^{+}$386.0379, found 386.0382 .

N-((5,7-Dichloro-8-hydroxyquinolin-2-yl)methyl)-5-methoxy-1H-indole-2-carboxamide (12b): ${ }^{1} \mathrm{H}-\mathrm{NMR}$ $\left(400 \mathrm{MHz}, \mathrm{DMSO}-\mathrm{d}_{6}\right): \delta 11.87(\mathrm{~s}, 1 \mathrm{H}), 10.64(\mathrm{~s}, 1 \mathrm{H}), 10.02(\mathrm{~s}, 1 \mathrm{H}), 8.56(\mathrm{~d}, J=8.8 \mathrm{~Hz}, 1 \mathrm{H}), 7.87$ $(\mathrm{d}, J=8.8 \mathrm{~Hz}, 1 \mathrm{H}), 7.8(\mathrm{~s}, 1 \mathrm{H}), 7.35(\mathrm{~d}, J=9.2 \mathrm{~Hz}, 1 \mathrm{H}), 7.2-7.19(\mathrm{~m}, 1 \mathrm{H}), 7.11(\mathrm{~d}, J=2.4 \mathrm{~Hz}, 1 \mathrm{H}), 6.94$ $(\mathrm{dd}, J=8.8,2.4 \mathrm{~Hz}, 1 \mathrm{H}), 5.67(\mathrm{~s}, 2 \mathrm{H}), 3.74(\mathrm{~s}, 3 \mathrm{H}) \mathrm{ppm} ;{ }^{13} \mathrm{C}-\mathrm{NMR}\left(100 \mathrm{MHz}, \mathrm{DMSO}-d_{6}\right): \delta 161.26$, $157.04,154.46,149.21,138.68,134.49,133.43,128.26,127.47,127.10,124.60,121.59,119.58,117.13,116.55$, $113.98,108.68,102.37,66.93,55.65 \mathrm{ppm}$. HR-MS (ESI) $\mathrm{m} / z$ calcd for $\mathrm{C}_{20} \mathrm{H}_{15} \mathrm{Cl}_{2} \mathrm{~N}_{3} \mathrm{O}_{3}(\mathrm{M}+\mathrm{H})^{+} 416.0485$, found 416.0492 .

Synthesis of (8-((tert-butoxycarbonyl)oxy)quinolin-2-yl)methyl-1H-1,2,4-triazole-1-carboxylates 14a-14c:

To a stirred solution of an appropriate tert-butyl (2-(hydroxymethyl)quinolin-8-yl) carbonate $(4 \mathbf{a}-4 \mathrm{c})(1 \mathrm{mmol})$ in dichloromethane was added carbonylditriazole $(2 \mathrm{mmol})$ at room temperature. The reaction mixture was stirred for $30 \mathrm{~min}$. After completion of the reaction, water was added and the resulting mixture was extracted with dichloromethane, the separated organic layer dried over $\mathrm{Na}_{2} \mathrm{SO}_{4}$ and concentrated under reduced pressure to afford triazole intermediates 14a-14c. 
(8-((tert-Butoxycarbonyl)oxy)quinolin-2-yl)methyl-1H-1,2,4-triazole-1-carboxylate (14a):

${ }^{1} \mathrm{H}-\mathrm{NMR}\left(400 \mathrm{MHz}, \mathrm{CDCl}_{3}\right): \delta 8.88(\mathrm{~s}, 1 \mathrm{H}), 8.27(\mathrm{~d}, J=8.5 \mathrm{~Hz}, 1 \mathrm{H}), 8.11(\mathrm{~s}, 1 \mathrm{H}), 7.74(\mathrm{dd}, J=6.6,3.0 \mathrm{~Hz}$, $1 \mathrm{H}), 7.63(\mathrm{~d}, J=8.5 \mathrm{~Hz}, 1 \mathrm{H}), 7.58-7.50(\mathrm{~m}, 2 \mathrm{H}), 5.77(\mathrm{~s}, 2 \mathrm{H}), 1.59(\mathrm{~s}, 9 \mathrm{H})$ ppm. ${ }^{13} \mathrm{C}-\mathrm{NMR}(101 \mathrm{MHz}$, $\left.\mathrm{CDCl}_{3}\right): \delta 153.83,153.68,151.83,147.28,145.79,140.60,137.46,128.89,126.90,125.61,121.67,119.87$, 83.70, 71.17, $27.62 \mathrm{ppm}$.

(8-((tert-Butoxycarbonyl)oxy)-5,7-dichloroquinolin-2-yl)methyl-1H-1,2,4-triazole-1-carboxylate $(14 b)$ :

${ }^{1} \mathrm{H}-\mathrm{NMR}\left(400 \mathrm{MHz}, \mathrm{CDCl}_{3}\right): \delta 8.89(\mathrm{~s}, 1 \mathrm{H}), 8.59(\mathrm{~d}, J=8.8 \mathrm{~Hz}, 1 \mathrm{H}), 8.11(\mathrm{~s}, 1 \mathrm{H}), 7.71(\mathrm{~d}, J=8.4 \mathrm{~Hz}$, 2H), 5.77 (s, 2H), 1.57 (s, 9H) ppm. ${ }^{13} \mathrm{C}-\mathrm{NMR}\left(101 \mathrm{MHz}, \mathrm{CDCl}_{3}\right): \delta 155.61,153.90,150.35,145.84,142.78$, $141.72,134.77,128.95,127.86,125.42,120.29,84.57,70.38,27.54$ ppm.

(8-((tert-Butoxycarbonyl)oxy)-5,7-dibromoquinolin-2-yl)methyl-1H-1,2,4-triazole-1-carboxylate (14c):

${ }^{1} \mathrm{H}-\mathrm{NMR}\left(400 \mathrm{MHz}, \mathrm{CDCl}_{3}\right): \delta 8.89(\mathrm{~s}, 1 \mathrm{H}), 8.54(\mathrm{~d}, J=8.7 \mathrm{~Hz}, 1 \mathrm{H}), 8.08(\mathrm{~d}, J=30.9 \mathrm{~Hz}, 2 \mathrm{H}), 7.71(\mathrm{~d}$, $J=8.8 \mathrm{~Hz}, 1 \mathrm{H}), 5.78(\mathrm{~s}, 2 \mathrm{H}), 1.58(\mathrm{~s}, 9 \mathrm{H}) \mathrm{ppm} .{ }^{13} \mathrm{C}-\mathrm{NMR}\left(1010 \mathrm{MHz}, \mathrm{CDCl}_{3}\right): \delta 155.53,153.88,150.16$, 147.26, 145.86, 144.92, 141.67, 137.30, 133.51, 127.12, 120.74, 118.92, 117.35, 84.52, 70.23, 27.55 ppm.

Synthesis of hybrid (8-((tert-butoxycarbonyl)oxy)quinolin-2-yl)methylpiperazine-1- carboxylates 16a-16c:

An appropriate triazole intermediate $(\mathbf{1 4 a}-\mathbf{1 4 c})(1 \mathrm{mmol})$ was dissolved in dichloromethane $(2 \mathrm{~mL})$ and treated with piperazine $(15)(1.0 \mathrm{mmol})$ at room temperature for $1 \mathrm{~h}$. Completion of the reaction was monitored by TLC. Water $(2 \mathrm{~mL})$ was then added and the resulting mixture was extracted with dichloromethane $(2 \times 3 \mathrm{~mL})$, the organic layer separated, dried over anhydrous $\mathrm{Na}_{2} \mathrm{SO}_{4}$ and concentrated to afford the appropriate Boc-protected product (16a-16c). The crude product was purified by column chromatography (silica gel, $2 \%$ methanol in dichloromethane) to afford the desired product (16a-16c).

(8-((tert-Butoxycarbonyl)oxy)quinolin-2-yl)methyl-piperazine-1-carboxylate (16a): ${ }^{1} \mathrm{H}-\mathrm{NMR}(400 \mathrm{MHz}$, DMSO- $\left.d_{6}\right): \delta 8.33(\mathrm{~d}, J=8.4 \mathrm{~Hz}, 1 \mathrm{H}), 7.52(\mathrm{~d}, J=8.4 \mathrm{~Hz}, 1 \mathrm{H}), 7.45-7.35(\mathrm{~m}, 2 \mathrm{H}), 7.10(\mathrm{dd}, J=7.2$, $1.2 \mathrm{~Hz}, 1 \mathrm{H}), 5.33(\mathrm{~s}, 2 \mathrm{H}), 3.37(\mathrm{~m}, 4 \mathrm{H}), 2.72-2.61(\mathrm{~m}, 4 \mathrm{H}), 1.58(\mathrm{~s}, 9 \mathrm{H})$ ppm; ${ }^{13} \mathrm{C}-\mathrm{NMR}(101 \mathrm{MHz}$, DMSO- $d_{6}$ ): $\delta 155.59,154.75,153.35,153.22,137.99,137.42,128.43,127.80,119.91,118.08,112.07,67.84$, $45.81,27.52 \mathrm{ppm}$.

(8-((tert-Butoxycarbonyl)oxy)-5,7-dichloro-8-hydroxyquinolin-2-yl)methyl-piperazine-1-carboxylate (16b): ${ }^{1} \mathrm{H}-\mathrm{NMR}\left(400 \mathrm{MHz}, \mathrm{CDCl}_{3}\right): \delta 8.39(\mathrm{~d}, J=8.4 \mathrm{~Hz}, 1 \mathrm{H}), 7.52(\mathrm{~d}, J=8.8 \mathrm{~Hz}, 1 \mathrm{H}), 7.48(\mathrm{~s}, 1 \mathrm{H})$, $5.37(\mathrm{~s}, 2 \mathrm{H}), 3.59(\mathrm{~m}, 4 \mathrm{H}), 2.88(\mathrm{br}-\mathrm{s}, 4 \mathrm{H}), 1.57(\mathrm{~s}, 9 \mathrm{H}) \mathrm{ppm} ;{ }^{13} \mathrm{C}-\mathrm{NMR}\left(101 \mathrm{MHz}, \mathrm{CDCl}_{3}\right): \delta 156.66,153.64$, 154.82, 147.78, 137.93, 134.32, 128.07, 124.18, 120.40, 120.31, 115.78, 67.22, 53.42, 45.49, 27.52 ppm.

(8-((tert-Butoxycarbonyl)oxy)-5,7-dibromo-8-hydroxyquinolin-2-yl)methyl-piperazine-1-carboxylate (16c): ${ }^{1} \mathrm{H}-\mathrm{NMR}\left(400 \mathrm{MHz}, \mathrm{DMSO}-d_{6}\right): \delta 8.40(\mathrm{~d}, J=8.8 \mathrm{~Hz}, 1 \mathrm{H}), 7.97(\mathrm{~s}, 1 \mathrm{H}), 7.68(\mathrm{~d}, J=8.8 \mathrm{~Hz}, 1 \mathrm{H})$, $5.38(\mathrm{~s}, 2 \mathrm{H}), 3.46(\mathrm{~m}, 4 \mathrm{H}), 2.80$ (br-s, 4H), 1.58 (s, 9H) ppm; ${ }^{13} \mathrm{C}-\mathrm{NMR}\left(101 \mathrm{MHz}, \mathrm{DMSO}-d_{6}\right): \delta 156.92$, 154.60, 153.55 153.13, 139.44, 136.71, 133.63, 126.37, 121.45, 106.98, 106.32, 67.49, 45.01, 44.33, 27.51 ppm.

Synthesis of (8-hydroxyquinolin-2-yl)methyl-4-(1H-indole-2-carbonyl)piperazine-1-carboxylate hybrid derivatives (18a-18h):

To the stirred solution of an appropriate indole-2-carboxylic acid (5a-5c) $(0.15 \mathrm{mmol})$ in dry dichloromethane $(5 \mathrm{~mL})$ under an argon atmosphere at $0{ }^{\circ} \mathrm{C}$ was added $\mathrm{EDCI}(0.181 \mathrm{mmol})$, and the mixture allowed to stir for $15 \mathrm{~min}$. A catalytic amount of DMAP $(0.045 \mathrm{mmol})$ was then added, followed by addition of an appropriate (8-((tert-butoxycarbonyloxy)-quinolin-2-yl)methyl piperazine-1-carboxylate $(\mathbf{1 6 a}-\mathbf{1 6 c})(0.151 \mathrm{mmol})$ in dry dichloromethane $(3 \mathrm{~mL})$ at $0{ }^{\circ} \mathrm{C}$. The resulting mixture was stirred for $8 \mathrm{~h}$ at room temperature. After completion of the reaction (monitoring by TLC), the reaction mixture was washed with water $(10 \mathrm{~mL})$ and 
the dichloromethane layer separated, dried over anhydrous sodium sulfate, filtered, and concentrated. The crude material was purified by silica gel column chromatography, using $2-5 \%$ methanolic dichloromethane as eluent, to afford the corresponding (8-((tert-butoxycarbonyl)oxy) quinolin-2-yl)methyl-4-(1H-indole-2-carbonyl)piperazine-1-carboxylate hybrid derivatives (17a-17h), which was dissolved in a mixture of DCM $(10 \mathrm{~mL})$ and TFA $(1.0 \mathrm{~mL})$ and stirred for $6 \mathrm{~h}$ until Boc-deprotection was completed. Saturated $\mathrm{NaHCO}_{3}$ solution $(20 \mathrm{~mL})$ was then added to the resulting mixture which was extracted with dichloromethane. The organic layer was separated and washed with water, followed by brine solution, dried over anhydrous $\mathrm{Na}_{2} \mathrm{SO}_{4}$ and concentrated to afford the corresponding (8-hydroxyquinolin-2-yl)methyl-4-(1H-indole-2-carbonyl)piperazine-1- carboxylate hybrid derivative (18a-18h).

(8-Hydroxyquinolin-2-yl)methyl-4-(1H-indole-2-carbonyl)piperazine-1-carboxylate (18a): ${ }^{1} \mathrm{H}-\mathrm{NMR}(400 \mathrm{MHz}$, $\left.\mathrm{CDCl}_{3}\right): \delta 9.67(\mathrm{~s}, 1 \mathrm{H}), 8.19(\mathrm{~d}, J=8.4 \mathrm{~Hz}, 1 \mathrm{H}), 7.65(\mathrm{~d}, J=8.0 \mathrm{~Hz}, 1 \mathrm{H}), 7.52-7.42(\mathrm{~m}, 3 \mathrm{H}), 7.35-7.2(\mathrm{~m}$, 2H), 7.20-7.12 (m, 2H), $6.78(\mathrm{~s}, 1 \mathrm{H}), 5.45(\mathrm{~s}, 2 \mathrm{H}), 3.96(\mathrm{~s}, 4 \mathrm{H}), 3.70(\mathrm{~s}, 4 \mathrm{H})$ ppm; ${ }^{13} \mathrm{C}-\mathrm{NMR}(100 \mathrm{MHz}$, $\left.\mathrm{CDCl}_{3}\right): \delta 162.82,154.94,154.26,151.88,137.07,127.85,124.64,121.87,120.66,120.06,117.73,111.71$, $110.44,105.49,68.12,43.74$ ppm. HR-MS (ESI) $m / z$ calcd for $\mathrm{C}_{24} \mathrm{H}_{22} \mathrm{~N}_{4} \mathrm{O}_{4}(\mathrm{M}+\mathrm{H})^{+} 431.1708$, found 431.1712 .

(5,7-Dibromo-8-hydroxyquinolin-2-yl)methyl-4-(1H-indole-2-carbonyl)piperazine-1-carboxylate (18b): ${ }^{1} \mathrm{H}-\mathrm{NMR}\left(400 \mathrm{MHz}, \mathrm{CDCl}_{3}\right): \delta 9.50(\mathrm{~s}, 1 \mathrm{H}), 8.44(\mathrm{~d}, J=8.8 \mathrm{~Hz}, 1 \mathrm{H}), 7.86(\mathrm{~s}, 1 \mathrm{H}), 7.61(\mathrm{dd}, J=15.2$, $8.4 \mathrm{~Hz}, 2 \mathrm{H}), 7.41(\mathrm{~d}, J=8.0 \mathrm{~Hz}, 1 \mathrm{H}), 7.28(\mathrm{t}, J=7.6 \mathrm{~Hz}, 1 \mathrm{H}), 7.13(\mathrm{t}, J=7.6 \mathrm{~Hz}, 1 \mathrm{H}), 6.76(\mathrm{~s}, 1 \mathrm{H}), 5.46(\mathrm{~s}$, 2H), $3.96(\mathrm{~s}, 4 \mathrm{H}), 3.68(\mathrm{~s}, 4 \mathrm{H}) \mathrm{ppm} ;{ }^{13} \mathrm{C}-\mathrm{NMR}\left(100 \mathrm{MHz}, \mathrm{CDCl}_{3}\right): \delta 162.75,156.36,154.69,149.35,137.77$, $137.09,135.75,133.78,128.62,127.32,125.92,124.69,121.91,121.05,120.73,111.78,110.07,105.50,104.33$, $67.38,44.03$ ppm. HR-MS (ESI) $m / z$ calcd for $\mathrm{C}_{24} \mathrm{H}_{20} \mathrm{Br}_{2} \mathrm{~N}_{4} \mathrm{O}_{4}(\mathrm{M}+\mathrm{H})^{+} 588.9879$, found 588.9885 .

(5,7-Dichloro-8-hydroxyquinolin-2-yl)methyl-4-(1H-indole-2-carbonyl)piperazine-1-carboxylate (18c): ${ }^{1} \mathrm{H}-\mathrm{NMR}\left(400 \mathrm{MHz}, \mathrm{CDCl}_{3}\right): \delta 10.08(\mathrm{~s}, 1 \mathrm{H}), 8.41(\mathrm{~d}, J=8.8 \mathrm{~Hz}, 1 \mathrm{H}), 7.63(\mathrm{~d}, J=7.6 \mathrm{~Hz}, 1 \mathrm{H}), 7.56(\mathrm{~d}$, $J=8.4 \mathrm{~Hz}, 1 \mathrm{H}), 7.5(\mathrm{~s}, 1 \mathrm{H}), 7.42(\mathrm{~d}, J=7.6 \mathrm{~Hz}, 1 \mathrm{H}), 7.27(\mathrm{~d}, J=7.6 \mathrm{~Hz}, 1 \mathrm{H}), 7.13(\mathrm{t}, J=7.2 \mathrm{~Hz}, 1 \mathrm{H})$, $6.76(\mathrm{~s}, 1 \mathrm{H}), 5.45(\mathrm{~s}, 2 \mathrm{H}), 3.99(\mathrm{~s}, 4 \mathrm{H}), 3.7(\mathrm{~s}, 4 \mathrm{H}) \mathrm{ppm} .{ }^{13} \mathrm{C}-\mathrm{NMR}\left(100 \mathrm{MHz}, \mathrm{CDCl}_{3}\right): \delta 162.98,156.40$, 154.75, 147.29, 137.69, 135.95, 134.42, 128.61, 128.14, 127.22, 124.54, 124.13, 121.84, 120.68, 120.61, 120.45, $115.68,111.89,105.52,67.48,43.82$ ppm. HR-MS (ESI) $\mathrm{m} / z$ calcd for $\mathrm{C}_{24} \mathrm{H}_{20} \mathrm{Cl}_{2} \mathrm{~N}_{4} \mathrm{O}_{4}(\mathrm{M}+\mathrm{H})^{+} 499.0925$, found 499.0929 .

(8-Hydroxyquinolin-2-yl)methyl-4-(5-methoxy-1H-indole-2-carbonyl)piperazine-1-carboxylate (18d): ${ }^{1} \mathrm{H}-\mathrm{NMR}$ (400 MHz, DMSO- $\left.d_{6}\right): \delta 11.46(\mathrm{~s}, 1 \mathrm{H}), 9.64(\mathrm{~s}, 1 \mathrm{H}), 8.34(\mathrm{~d}, J=8.4 \mathrm{~Hz}, 1 \mathrm{H}), 7.58(\mathrm{~d}, J=8.4 \mathrm{~Hz}, 1 \mathrm{H})$, $7.45-7.38(\mathrm{~m}, 2 \mathrm{H}), 7.33(\mathrm{~d}, J=8.8 \mathrm{~Hz}, 1 \mathrm{H}), 7.12(\mathrm{~d}, J=6.8 \mathrm{~Hz}, 1 \mathrm{H}), 7.07(\mathrm{~s}, 1 \mathrm{H}), 6.86(\mathrm{dd}, J=8.8,2.4 \mathrm{~Hz}$, $1 \mathrm{H}), 6.75(\mathrm{~s}, 1 \mathrm{H}), 5.38(\mathrm{~s}, 2 \mathrm{H}), 3.81$ (br-s, $4 \mathrm{H}), 3.75(\mathrm{~s}, 3 \mathrm{H}), 3.63(\mathrm{br}-\mathrm{s}, 2 \mathrm{H}), 3.56$ (br-s, 2H) ppm; ${ }^{13} \mathrm{C}-\mathrm{NMR}$ $\left(100 \mathrm{MHz}\right.$, DMSO- $\left.d_{6}\right): \delta 162.65,155.37,154.78,154.18,153.37,138.03,137.43,131.66,130.37,128.50$, $127.83,127.52,120.01,118.13,114.89,113.36,112.13,104.51,102.31,68.09,55.66,44.04$ ppm. HR-MS (ESI) $m / z$ calcd for $\mathrm{C}_{25} \mathrm{H}_{24} \mathrm{~N}_{4} \mathrm{O}_{5}(\mathrm{M}+\mathrm{H})^{+} 461.1811$, found 461.1813 .

(5,7-Dibromo-8-hydroxyquinolin-2-yl)methyl-4-(5-methoxy-1H-indole-2-carbonyl)piperazine-1-carboxylate (18e): ${ }^{1} \mathrm{H}-\mathrm{NMR}\left(400 \mathrm{MHz}, \mathrm{DMSO}-d_{6}\right): \delta 11.46(\mathrm{~s}, 1 \mathrm{H}), 8.48(\mathrm{~d}, J=8.8 \mathrm{~Hz}, 1 \mathrm{H}), 8.05(\mathrm{~s}, 1 \mathrm{H}), 7.8(\mathrm{~d}$, $J=8.8 \mathrm{~Hz}, 1 \mathrm{H}), 7.33(\mathrm{~d}, J=9.2 \mathrm{~Hz}, 1 \mathrm{H}), 7.07(\mathrm{~d}, J=2.0 \mathrm{~Hz}, 1 \mathrm{H}), 6.85(\mathrm{dd}, J=8.8,2.4 \mathrm{~Hz}, 1 \mathrm{H}), 6.75(\mathrm{~s}$, 1H), 5.45 (s, 2H), $3.821(\mathrm{~s}, 4 \mathrm{H}), 3.75$ (s, 3H), 3.65 (br-s, 4H) ppm. ${ }^{13} \mathrm{C}-\mathrm{NMR}\left(100 \mathrm{MHz}\right.$, DMSO-d $\left.{ }_{6}\right): \delta$ 162.66, 157.61, 154.62, 154.18, 151.04, 138.57, 136.89, 133.57, 131.66, 130.35, 127.51, 126.16, 121.75, 114.90, $113.36,109.33,105.98,104.52,102.30,67.54,55.67 \mathrm{ppm}$. HR-MS (ESI) $\mathrm{m} / z$ calcd for $\mathrm{C}_{25} \mathrm{H}_{22} \mathrm{Br}_{2} \mathrm{~N}_{4} \mathrm{O}_{5}(\mathrm{M}+$ $\mathrm{H})^{+}$618.9998, found 619.0000 .

(5,7-Dichloro-8-hydroxyquinolin-2-yl)methyl-4-(5-methoxy-1H-indole-2-carbonyl)piperazine-1-carboxylate (18f): ${ }^{1} \mathrm{H}-\mathrm{NMR}\left(400 \mathrm{MHz}, \mathrm{DMSO}-d_{6}\right): \delta 11.46(\mathrm{~s}, 1 \mathrm{H}), 8.54(\mathrm{~d}, J=8.8 \mathrm{~Hz}, 1 \mathrm{H}), 7.80(\mathrm{~s}, 1 \mathrm{H}), 7.78(\mathrm{~d}$, $J=8.8 \mathrm{~Hz}, 1 \mathrm{H}), 7.33(\mathrm{~d}, J=8.8 \mathrm{~Hz}, 1 \mathrm{H}), 7.06(\mathrm{~d}, J=2.4 \mathrm{~Hz}, 1 \mathrm{H}), 6.85(\mathrm{dd}, J=8.8,2.4 \mathrm{~Hz}, 1 \mathrm{H}), 6.74(\mathrm{~s}, 1 \mathrm{H})$, $5.44(\mathrm{~s}, 2 \mathrm{H}), 4.04(\mathrm{~s}, 2 \mathrm{H}), 3.82(\mathrm{~s}, 2 \mathrm{H}), 3.75(\mathrm{~s}, 3 \mathrm{H}), 3.66(\mathrm{~s}, 2 \mathrm{H}), 3.54(\mathrm{~s}, 2 \mathrm{H})$ ppm; ${ }^{13} \mathrm{C}-\mathrm{NMR}(100 \mathrm{MHz}$, DMSO- $\left.d_{6}\right): \delta 162.66,162.61,157.66,154.61,154.17,149.09,138.58,134.32,131.65,131.50,130.32,130.18$, 
$128.09,127.49,127.45,124.49,121.23,119.58,116.43,114.88,113.34,113.29,104.49,104.45,102.25,67.63$, $44.09,40.54,40.33,40.12,39.91,39.70,39.49,39.28$ ppm. HR-MS (ESI) m/z calcd for $\mathrm{C}_{25} \mathrm{H}_{22} \mathrm{Cl}_{2} \mathrm{~N}_{4} \mathrm{O}_{5}(\mathrm{M}+$ $\mathrm{H})^{+} 529.1026$, found 529.1031 .

(5,7-Dichloro-8-hydroxyquinolin-2-yl)methyl-4-(5-fluoro-1H-indole-2-carbonyl)piperazine-1-carboxylate (18g): ${ }^{1} \mathrm{H}-\mathrm{NMR}\left(400 \mathrm{MHz}, \mathrm{DMSO}-\mathrm{d}_{6}\right): \delta 11.73(\mathrm{~s}, 1 \mathrm{H}), 8.52(\mathrm{~d}, J=8.8 \mathrm{~Hz}, 1 \mathrm{H}), 7.80(\mathrm{~s}, 1 \mathrm{H}), 7.77(\mathrm{~d}, J=8.8 \mathrm{~Hz}$, $1 \mathrm{H}), 7.43(\mathrm{dd}, J=8.8,4.8 \mathrm{~Hz}, 1 \mathrm{H}), 7.37(\mathrm{~d}, J=10.0 \mathrm{~Hz}, 1 \mathrm{H}), 7.05(\mathrm{t}, J=9.2 \mathrm{~Hz}, 1 \mathrm{H}), 6.83(\mathrm{~s}, 1 \mathrm{H}), 5.44(\mathrm{~s}$, 2H), 3.82 (s, 4H), 3.66 (br-s, 2H), 3.55 (br-s, 2H) ppm. ${ }^{13} \mathrm{C}-\mathrm{NMR}\left(100 \mathrm{MHz}, \mathrm{DMSO}-d_{6}\right): \delta 162.35,158.72$, $157.60,156.40,154.62,149.28,138.66,134.30,133.13,131.83,128.11,127.33,127.22,124.50,121.22,119.42$, $116.47,113.77,113.67,112.57,112.31,106.04,105.81,104.72,104.67,67.66,43.92$ ppm. HR-MS (ESI) m/z calcd for $\mathrm{C}_{24} \mathrm{H}_{19} \mathrm{Cl}_{2} \mathrm{FN}_{4} \mathrm{O}_{4}(\mathrm{M}+\mathrm{H})^{+}$517.0829, found 517.0833.

(5,7-Dibromo-8-hydroxyquinolin-2-yl)methyl-4-(5-fluoro-1H-indole-2-carbonyl)piperazine-1-carboxylate (18h): ${ }^{1} \mathrm{H}-\mathrm{NMR}\left(400 \mathrm{MHz}, \mathrm{DMSO}-\mathrm{d}_{6}\right): \delta 11.72(\mathrm{~s}, 1 \mathrm{H}), 9.65(\mathrm{~s}, 1 \mathrm{H}), 8.35(\mathrm{~d}, J=8.4 \mathrm{~Hz}, 1 \mathrm{H}), 7.58(\mathrm{~d}, J=8.4 \mathrm{~Hz}$, $1 \mathrm{H}), 7.45-7.35(\mathrm{~m}, 4 \mathrm{H}), 7.12-7.03(\mathrm{~m}, 2 \mathrm{H}), 6.83(\mathrm{~d}, \mathrm{~J}=1.6 \mathrm{~Hz}, 1 \mathrm{H}), 5.38(\mathrm{~s}, 2 \mathrm{H}), 3.81$ (br-s, 4H), 3.63 (br-s, 2H), 3.54 (br-s, 2H) ppm. ${ }^{13} \mathrm{C}-\mathrm{NMR}\left(101 \mathrm{MHz}, \mathrm{DMSO}-d_{6}\right): \delta 162.33,158.71,156.39,155.35,154.78,153.35$, 138.01, 137.44, 133.12, 131.83, 128.50, 127.84, 127.33, 127.22, 120.01, 118.14, 113.77, 113.67, 112.57, 112.31, $112.14,106.05,105.82,104.74,104.69,68.09,44.0$. HR-MS (ESI) $m / z$ calcd for $\mathrm{C}_{24} \mathrm{H}_{21} \mathrm{FN}_{4} \mathrm{O}_{4}(\mathrm{M}+\mathrm{H})^{+}$ 449.1621 , found 449.1616 .

\subsection{Methodology for the In Vitro Self-Induced $A \beta_{1-42}$ Aggregation Assay}

The thioflavin T (ThT)-fluorescence assay was used to measure the inhibition of A $\beta$ aggregation [42]. $\mathrm{A} \beta_{1-42}$ (Adooq Bioscience, CA, USA) was pretreated with $1 \mathrm{~mL}$ of hexafluoroisopropanol (HFIP) to afford a stock solution, which was aliquoted into small samples. The solvent was evaporated at room temperature, and samples were stored at $-80{ }^{\circ} \mathrm{C}$. For $\mathrm{A} \beta_{1-42}$ aggregation inhibition experiments, phosphate buffer ( $\mathrm{pH} 7.4$ ) was added to the $\mathrm{A} \beta$ stock solution to afford a $50 \mu \mathrm{M}$ concentration before use. A mixture of the $\mathrm{A} \beta_{1-42}$ peptide $(10 \mu \mathrm{L}, 25 \mu \mathrm{M}$ final concentration) with or without the test compound $(10 \mu \mathrm{L} ; 0.3,1.0,3,9$, and $27 \mu \mathrm{M})$ was incubated at $37^{\circ} \mathrm{C}$ for $48 \mathrm{~h}$. Blanks using phosphate buffer ( $\mathrm{pH}$ 7.4) instead of $\mathrm{A} \beta$, with or without test compound, were also assessed. Then $50 \mathrm{mM}$ glycine- $\mathrm{NaOH}$ buffer ( $\mathrm{pH} 8.0)$ containing ThT $(5 \mu \mathrm{M})$ was added to $20 \mu \mathrm{L}$ of the sample to afford a final volume of $200 \mu \mathrm{L}$. The fluorescence intensities were recorded (excitation, $450 \mathrm{~nm}$; emission, $485 \mathrm{~nm}$ ). The fluorescence intensities were background corrected to the no enzyme control and 100\% of intensity reflected no inhibition of aggregation. To obtain the normalized amyloid aggregation inhibition relative to the control group, the amyloid aggregation/cell values were further divided by the total amyloid fluorescence of the control group. Using GraphPad Prism, the amyloid aggregation values (relative to control group) were entered along the corresponding concentrations for the triplicates and then a log transformation was obtained. Using the dose-response simulation module in GraphPad Prism, nonlinear regression fit (curve) was then generated for each small molecule with various concentrations used. Curves were then compared to determine if they were statistically different, by performing the best-fit values of selected unshared parameters between data sets and extra sum-of-squares $\mathrm{F}$ test, allowing for selection of the simpler model unless the $P$ value was less than 0.05 . The $\log \mathrm{EC}_{50}$ output parameter was then selected to obtain the $\mathrm{EC}_{50}$ for each of the dose-response curves for the small molecules.

\subsection{Methodology for the In Vitro Metal-Induced $A \beta_{1-42}$ Aggregation Assay}

For the inhibition of copper- and zinc-mediated $\mathrm{A} \beta_{1-42}$ aggregation, $20 \mu \mathrm{M}$ HEPES (pH 6.6) in $150 \mu \mathrm{M} \mathrm{NaCl}$ was added to the $\mathrm{A} \beta_{1-42}$ stock solution to afford a $25 \mu \mathrm{M}$ solution. Mixtures of the peptide (10 $\mu \mathrm{L}, 25 \mu \mathrm{M}$ final concentration) with or without $\mathrm{Cu}^{2+}$ or $\mathrm{Zn}^{2+}(10 \mu \mathrm{L}, 25 \mu \mathrm{M}$ final concentration) and the test compound ( $10 \mu \mathrm{L}, 50 \mu \mathrm{M}$ final concentration) were incubated at $37{ }^{\circ} \mathrm{C}$ for $24 \mathrm{~h}$. Then $50 \mathrm{mM}$ glycine-NaOH buffer ( $\mathrm{pH} 8.0)$ containing ThT $(5 \mu \mathrm{M})$ was added to $20 \mu \mathrm{L}$ of the sample and diluted to afford a final volume of $200 \mu \mathrm{L}$. Fluorescence intensities of the solutions were recorded 
(excitation, $450 \mathrm{~nm}$; emission, $485 \mathrm{~nm}$ ). The percentage of aggregation was calculated by the expression $(1-\mathrm{IFi} / \mathrm{IFc}) \times 100$, in which IFi and IFc are the fluorescence intensities obtained for $\mathrm{A} \beta$ in the presence and absence of inhibitors, respectively.

\subsection{Methodology for the Metal-Chelation Study}

The chelating studies were performed with a UV-vis spectrophotometer. The absorption spectra of test compound ( $50 \mu \mathrm{M}$, final concentration) alone or in the presence of $\mathrm{CuSO}_{4}, \mathrm{FeSO}_{4}, \mathrm{Or}_{\mathrm{ZnCl}}$ (50 $\mu \mathrm{M}$, final concentration) in buffer (20 mM HEPES, $150 \mathrm{mM} \mathrm{NaCl}, \mathrm{pH} 7.4$ ) were incubated for $30 \mathrm{~min}$ and then recorded at room temperature, respectively. For the stoichiometry of the test compound-Cu ${ }^{2+}$ complex or the test compound- $\mathrm{Zn}^{2+}$ complex, a fixed amount of test compound $(50 \mu \mathrm{M})$ was mixed with increasing amounts of copper ion or $\mathrm{Zn}$ ion $(0-100 \mu \mathrm{M})$, and the UV-vis difference spectra were analyzed to determine the ratio of ligand/metal ion in the complex.

\subsection{Methodology for In Vitro HEK-Tau and SY5Y-APP ${ }_{S w}$ Cell Aggregation Assays}

Human Embryonic Kidney cells that overexpress tau protein (HEK-tau) cells or SY5Y neuroblastoma cells that express a familial-AD mutant of amyloid precursor protein $\left(S Y 5 Y-A P P_{S w}\right.$ cells) were each seeded in 96-well plates at 8000 cells per well. After $24 \mathrm{~h}$, cells were supplemented with test compound at $1 \mu \mathrm{M}$ after diluting with medium. Vehicle only control was also included for each experiment. The cells were cultured for an additional $48 \mathrm{~h}$ at $37^{\circ} \mathrm{C}$. Both the cell lines were able to reach approximately $80 \%$ confluency in $48 \mathrm{~h}$. Cells were assessed for amyloid deposits by staining with $0.1 \%$ w $/ v$ ThT, counterstaining nuclei with DAPI, and calculating mean ThT fluorescence signal per nucleus over multiple fields.

\subsection{Methodology for Molecular Docking}

Molecular docking was performed using Schrodinger software Maestro 11.4 suite. The ligands were prepared using the LigPrep module. The protein crystal structure PDB ID: 1IYT was downloaded from the RCSB Protein Data Bank (https://www.rcsb.org/). The downloaded protein crystal structure was prepared in Protein Preparation Wizard wherein the missing hydrogens were added and bond orders assigned. A grid for docking the ligand was generated with the centroid of the co-crystallized ligand from PDB ID: 1IYT as the center of the grid with no constraints. The prepared ligands $\mathbf{1 8 d}$ and 18f were docked into this grid using Glide module. Molecular docking was performed at XP precision and results were analyzed in the Maestro visualizer.

Supplementary Materials: The following are available online.

Author Contributions: S.K.B.: Design, Synthesis and In vitro self-induced and metal-Induced A $\beta_{1-42}$ aggregation assay; N.M. and S.K. (Sesha Krishnamachari): In vitro HEK-Tau and SY5Y-APP ${ }_{\text {Sw }}$ cell culture experiments; S.A.: Design of screening the drugs against $A \beta_{1-42}$ aggregation and cell culture experiments; N.R.P.: Molecular docking studies; S.K. (Samuel Kakraba): Calculations of in vitro self-induced and metal-Induced A $\beta_{1-42}$ aggregation assay results; R.J.S.R.: Supervision and design of overall biological experiments; P.A.C.: Supervision and design of overall project; S.K.B. and N.R.P.: Manuscript preparation with additional inputs from P.A.C. All authors have read and agreed to the published version of the manuscript.

Funding: We are grateful for research support from the National Institutes of Health, NIA grant P01 AG012411 (S. Griffin, P.I.) and from the U.S. Dept. of Veteran Affairs, Merit Award BX001655 (R. J. Shmookler Reis, P.I.); also a Senior Research Career Scientist Award BX004851 to R.J.S.R.; and an Arkansas Research Alliance Scholar award to P.A.C.

Conflicts of Interest: The authors declare no conflicts of interest.

\section{References}

1. Förstl, H.; Kurz, A. Clinical features of Alzheimer's disease. Eur. Arch. Psy. Clin. Neurosci. 1999, 249, $288-290$. [CrossRef] [PubMed]

2. Torre, J.D.; Aliev, G.; Perry, G. Drug Therapy in Alzheimer's Disease. N. Engl. J. Med. 2004, 351, $1911-1913$.

3. Querfurth, H.W.; LaFerla, F.M. Alzheimer's disease. N. Engl. J. Med. 2010, 362, 329-344. [CrossRef] 
4. Walsh, D.M.; Selkoe, D.J. Deciphering the molecular basis of memory failure in Alzheimer's disease. Neuron 2004, 44, 181-193. [CrossRef]

5. Munoz-Torrero, D. Acetylcholinesterase inhibitors as disease-modifying therapies for Alzheimer's disease. Curr. Med. Chem. 2008, 15, 2433-2455. [CrossRef]

6. Young, A.B. Four decades of neurodegenerative disease research: How far we have come! J. Neurosci. 2009, 29, 12722-12728. [CrossRef]

7. Spangenberg, E.E.; Green, K.N. Inflammation in Alzheimer's disease: Lessons learned from microglia-depletion models. Brain Behav. Immun. 2017, 61, 1-11. [CrossRef]

8. Deora, G.S.; Kantham, S.; Chan, S.; Dighe, S.N.; Veliyath, S.K.; McColl, G.; Parat, M.O.; McGeary, R.P.; Ross, B.P. Multifunctional Analogs of Kynurenic Acid for the Treatment of Alzheimer's Disease: Synthesis, Pharmacology, and Molecular Modeling Studies. ACS Chem. Neurosci. 2017, 8, 2667-2675. [CrossRef] [PubMed]

9. Hiremathad, A.; Keri, R.S.; Esteves, A.R.; Cardoso, S.M.; Chaves, S.; Santos, M.A. Novel Tacrine-Hydroxyphenylbenzimidazole hybrids as potential multitarget drug candidates for Alzheimer's disease. Eur. J. Med. Chem. 2018, 148, 255-267. [CrossRef] [PubMed]

10. Kumar, B.; Dwivedi, A.R.; Sarkar, B.; Gupta, S.K.; Krishnamurthy, S.; Mantha, A.K.; Parkash, J.; Kumar, V. 4,6-Diphenylpyrimidine Derivatives as Dual Inhibitors of Monoamine Oxidase and Acetylcholinesterase for the Treatment of Alzheimer's Disease. ACS Chem. Neurosci. 2019, 10, 252-265. [CrossRef]

11. Li, X.; Wang, H.; Xu, Y.; Liu, W.; Gong, Q.; Wang, W.; Qiu, X.; Zhu, J.; Mao, F.; Zhang, H.; et al. Novel Vilazodone-Tacrine Hybrids as Potential Multitarget-Directed Ligands for the Treatment of Alzheimer's Disease Accompanied with Depression: Design, Synthesis, and Biological Evaluation. ACS Chem. Neurosci. 2017, 8, 2708-2721. [CrossRef] [PubMed]

12. Sevigny, J.; Chiao, P.; Bussiere, T.; Weinreb, P.H.; Williams, L.; Maier, M.; Dunstan, R.; Salloway, S.; Chen, T.; Ling, Y.; et al. The antibody aducanumab reduces Abeta plaques in Alzheimer's disease. Nature 2016, 537, 50-56. [CrossRef] [PubMed]

13. Mohamed, T.; Shakeri, A.; Rao, P.P. Amyloid cascade in Alzheimer's disease: Recent advances in medicinal chemistry. Eur. J. Med. Chem. 2016, 113, 258-272. [CrossRef] [PubMed]

14. Viola, K.L.; Klein, W.L. Amyloid- $\beta$ oligomers in Alzheimer's disease pathogenesis, treatment, and diagnosis. Acta Neuropathol. 2015, 129, 183-206. [CrossRef]

15. Chang, L.; Cui, W.; Yang, Y.; Xu, S.; Zhou, W.; Fu, H.; Hu, S.; Mak, S.; Hu, J.; Wang, Q.; et al. Protection against $\beta$-amyloid-induced synaptic and memory impairments via altering $\beta$-amyloid assembly by bis(heptyl)-cognitin. Sci. Rep. 2015, 5, 10256. [CrossRef]

16. Zhao, L.N.; Long, H.; Mu, Y.; Chew, L.Y. The toxicity of amyloid $\beta$ oligomers. Int. J. Mol. Sci. 2012, 13, 7303-7327. [CrossRef]

17. Barnham, K.J.; Bush, A.I. Metals in Alzheimer's and Parkinson's diseases. Curr. Opin. Chem. Biol. 2008, 12, 222-228. [CrossRef]

18. Himes, R.A.; Park, G.Y.; Siluvai, G.S.; Blackburn, N.J.; Karlin, K.D. Structural studies of copper(I) complexes of amyloid- $\beta$ peptide fragments: Formation of two-coordinate bis(histidine) complexes. Angew. Chem. Int. Ed. Engl. 2008, 47, 9084-9087. [CrossRef]

19. Hou, L.; Zagorski, M.G. NMR reveals anomalous copper(II) binding to the amyloid Abeta peptide of Alzheimer's disease. J. Am. Chem. Soc. 2006, 128, 9260-9261. [CrossRef]

20. Duce, J.A.; Bush, A.I. Biological metals and Alzheimer's disease: Implications for therapeutics and diagnostics. Prog. Neurobiol. 2010, 92, 1-18. [CrossRef]

21. Kepp, K.P. Bioinorganic Chemistry of Alzheimer's Disease. Chem. Rev. 2012, 112, 5193-5239. [CrossRef] [PubMed]

22. Savelieff, M.G.; DeToma, A.S.; Derrick, J.S.; Lim, M.H. The ongoing search for small molecules to study metal-associated amyloid- $\beta$ species in Alzheimer's disease. Acc. Chem. Res. 2014, 47, 2475-2482. [CrossRef]

23. Kim, A.C.; Lim, S.; Kim, Y.K. Metal Ion Effects on A $\beta$ and Tau Aggregation. Int. J. Mol. Sci. 2018, $19,128$. [CrossRef] [PubMed] 
24. Ritchie, C.W.; Bush, A.I.; Mackinnon, A.; Macfarlane, S.; Mastwyk, M.; MacGregor, L.; Kiers, L.; Cherny, R.; Li, Q.X.; Tammer, A.; et al. Metal-protein attenuation with iodochlorhydroxyquin (clioquinol) targeting Abeta amyloid deposition and toxicity in Alzheimer disease: A pilot phase 2 clinical trial. Arch. Neurol. 2003, 60, 1685-1691. [CrossRef] [PubMed]

25. Cherny, R.A.; Atwood, C.S.; Xilinas, M.E.; Gray, D.N.; Jones, W.D.; McLean, C.A.; Barnham, K.J.; Volitakis, I.; Fraser, F.W.; Kim, Y.; et al. Treatment with a copper-zinc chelator markedly and rapidly inhibits $\beta$-amyloid accumulation in Alzheimer's disease transgenic mice. Neuron 2001, 30, 665-676. [CrossRef]

26. Adlard, P.A.; Cherny, R.A.; Finkelstein, D.I.; Gautier, E.; Robb, E.; Cortes, M.; Volitakis, I.; Liu, X.; Smith, J.P.; Perez, K.; et al. Rapid restoration of cognition in Alzheimer's transgenic mice with 8-hydroxy quinoline analogs is associated with decreased interstitial Abeta. Neuron 2008, 59, 43-55. [CrossRef]

27. Faux, N.G.; Ritchie, C.W.; Gunn, A.; Rembach, A.; Tsatsanis, A.; Bedo, J.; Harrison, J.; Lannfelt, L.; Blennow, K.; Zetterberg, H.; et al. PBT2 rapidly improves cognition in Alzheimer's Disease: Additional phase II analyses. J. Alzheimers Dis. 2010, 20, 509-516. [CrossRef]

28. Fernandez-Bachiller, M.I.; Perez, C.; Gonzalez-Munoz, G.C.; Conde, S.; Lopez, M.G.; Villarroya, M.; Garcia, A.G.; Rodriguez-Franco, M.I. Novel tacrine-8-hydroxyquinoline hybrids as multifunctional agents for the treatment of Alzheimer's disease, with neuroprotective, cholinergic, antioxidant, and copper-complexing properties. J. Med. Chem. 2010, 53, 4927-4937. [CrossRef]

29. Zheng, H.; Gal, S.; Weiner, L.M.; Bar-Am, O.; Warshawsky, A.; Fridkin, M.; Youdim, M.B. Novel multifunctional neuroprotective iron chelator-monoamine oxidase inhibitor drugs for neurodegenerative diseases: In vitro studies on antioxidant activity, prevention of lipid peroxide formation and monoamine oxidase inhibition. J. Neurochem. 2005, 95, 68-78. [CrossRef]

30. Zheng, H.; Youdim, M.B.; Fridkin, M. Site-activated multifunctional chelator with acetylcholinesterase and neuroprotective-neurorestorative moieties for Alzheimer's therapy. J. Med. Chem. 2009, 52, 4095-4098. [CrossRef]

31. Wang, Z.; Wang, Y.; Wang, B.; Li, W.; Huang, L.; Li, X. Design, Synthesis, and Evaluation of Orally Available Clioquinol-Moracin M Hybrids as Multitarget-Directed Ligands for Cognitive Improvement in a Rat Model of Neurodegeneration in Alzheimer's Disease. J. Med. Chem. 2015, 58, 8616-8637. [CrossRef] [PubMed]

32. López-Iglesias, B.; Pérez, C.; Morales-García, J.A.; Alonso-Gil, S.; Pérez-Castillo, A.; Romero, A.; López, M.G.; Villarroya, M.; Conde, S.; Rodríguez-Franco, M.I. New Melatonin- $N, N$-Dibenzyl( $N$-methyl)amine Hybrids: Potent Neurogenic Agents with Antioxidant, Cholinergic, and Neuroprotective Properties as Innovative Drugs for Alzheimer's Disease. J. Med. Chem. 2014, 57, 3773-3785. [CrossRef] [PubMed]

33. Ramirez-Rodriguez, G.; Klempin, F.; Babu, H.; Benitez-King, G.; Kempermann, G. Melatonin modulates cell survival of new neurons in the hippocampus of adult mice. Neuropsychopharmacology 2009, 34, 2180-2191. [CrossRef]

34. Yang, X.; Cai, P.; Liu, Q.; Wu, J.; Yin, Y.; Wang, X.; Kong, L. Novel 8-hydroxyquinoline derivatives targeting $\beta$-amyloid aggregation, metal chelation and oxidative stress against Alzheimer's disease. Bioorg. Med. Chem. 2018, 26, 3191-3201. [CrossRef] [PubMed]

35. Liang, S.H.; Southon, A.G.; Fraser, B.H.; Krause-Heuer, A.M.; Zhang, B.; Shoup, T.M.; Lewis, R.; Volitakis, I.; Han, Y.; Greguric, I.; et al. Novel Fluorinated 8-Hydroxyquinoline Based Metal Ionophores for Exploring the Metal Hypothesis of Alzheimer's Disease. ACS Med. Chem. Lett. 2015, 6, 1025-1029. [CrossRef] [PubMed]

36. Gil, V.M.S.; Oliveira, N.C. On the use of the method of continuous variations. J. Chem. Educ. 1990, 67, 473. [CrossRef]

37. Sensi, S.L.; Paoletti, P.; Koh, J.Y.; Aizenman, E.; Bush, A.I.; Hershfinkel, M. The neurophysiology and pathology of brain zinc. J. Neurosci. 2011, 31, 16076-16085. [CrossRef]

38. Crouch, P.J.; Savva, M.S.; Hung, L.W.; Donnelly, P.S.; Mot, A.I.; Parker, S.J.; Greenough, M.A.; Volitakis, I.; Adlard, P.A.; Cherny, R.A.; et al. The Alzheimer's therapeutic PBT2 promotes amyloid- $\beta$ degradation and GSK3 phosphorylation via a metal chaperone activity. J. Neurochem. 2011, 119, 220-230. [CrossRef]

39. Biancalana, M.; Koide, S. Molecular mechanism of Thioflavin-T binding to amyloid fibrils. Biochim. Biophys. Acta. 2010, 1804, 1405-1412. [CrossRef]

40. Crescenzi, O.; Tomaselli, S.; Guerrini, R.; Salvadori, S.; D’Ursi, A.M.; Temussi, P.A.; Picone, D. Solution structure of the Alzheimer amyloid $\beta$-peptide (1-42) in an apolar microenvironment. Similarity with a virus fusion domain. Eur. J. Biochem. 2002, 269, 5642-5648. [CrossRef] 
41. Du, H.; Liu, X.; Xie, J.; Ma, F. Novel Deoxyvasicinone-Donepezil Hybrids as Potential Multitarget Drug Candidates for Alzheimer's Disease. ACS Chem. Neurosci. 2019, 10, 2397-2407. [CrossRef] [PubMed]

42. Lu, C.; Guo, Y.; Yan, J.; Luo, Z.; Luo, H.-B.; Yan, M.; Huang, L.; Li, X. Design, Synthesis, and Evaluation of Multitarget-Directed Resveratrol Derivatives for the Treatment of Alzheimer's Disease. J. Med. Chem. 2013, 56, 5843-5859. [CrossRef] [PubMed]

Sample Availability: Samples of the compounds are available from the authors.

(C) 2020 by the authors. Licensee MDPI, Basel, Switzerland. This article is an open access article distributed under the terms and conditions of the Creative Commons Attribution (CC BY) license (http://creativecommons.org/licenses/by/4.0/). 